\title{
Genus Octospora (Pezizales) in Estonia and Finland
}

\author{
AIVO JAKOBSON, BELLIS KULLMAN and SEPPO HUHTINEN
}

\begin{abstract}
Jakobson, A., Kullman, B. \& Huhtinen, S. 1997: Genus Octospora (Pezizales) in Estonia and Finland. - Karstenia 38:1-25. Helsinki. ISSN 0453-3402

15 species of the genus Octospora have been found in Estonia and Finland. In Estonia 8 species have been found, of which 4 are new to Estonia: Octospora axillaris (Nees: Pers.) M.M. Moser, O. crosslandii (Dennis \& Itzerott) Benkert, O. rustica (Velen.) J. Moravec, O. wrightii (Berk. \& M.A. Curtis) J. Moravec, and 4 species recorded earlier, viz. O. carbonicola (Boud.) Yei-Zeng Wang, O. humosa (Fr.: Fr.) Dennis, O. leucoloma Hedw.: Gray and O. tetraspora (Fuckel) Korf. In Finland 11 species have been discovered. In addition to the earlier recorded $O$. seaveri (Benkert) Yei-Zeng Wang and $O$. maireana (Seaver) Yei-Zeng Wang, the following species have been found: O. alpestris (Sommerf.) Dennis \& Itzerott, O. borealis (Eckblad) Caillet \& Moyne, O. humosa (Fr. : Fr.) Dennis, O. leucoloma Hedw. : Gray, O. melina (Velen.) Dennis \& Itzerott, O. miniata (De Not.) Caillet \& Moyne, O. rubens (Boud.) M.M. Moser, O. rustica (Velen.) J. Moravec and O. wrightii (Berk. \& M.A. Curtis) J. Moravec.
\end{abstract}

Key words: Ascomycetes, Pezizales, Octospora, Lamprospora, taxonomy, morphology, fungal anatomy, new records, vital taxonomy

Aivo Jakobson, Institute of Botany and Ecology, University of Tartu, 40 Lai St., EE-2400 Tartu, Estonia

Bellis Kullman, Institute of Zoology and Botany, 181 Riia St., EE-2400 Tartu, Estonia

Seppo Huhtinen, Herbarium, FIN-20014 University of Turku, Finland

\section{Introduction}

The genus Octospora is treated in sensu Caillet and Moyne (1980). They transferred all species of the genus Lamprospora De Not. into the genus Octospora. This treatment is also supported by Wang and Kimbrough (1992) who established, by cladistic analysis, that the genus Lamprospora forms a paraphyletic group if it is treated separately from the genus Octospora. Several authors do not accept such a treatment (Engel \& Hanff 1985, 1987; Benkert 1987, 1990; Schumacher 1993). However, no differences are found in the anatomy of apothecial structure between the genera Octospora and Lamprospora.

More than 70 species have been described in the genus Octospora (Itzerott 1981, Benkert
1987, Caillet \& Moyne 1980, 1987); 23 species are known from Nordic countries (Dissing 1981; Dissing \& Sivertsen 1983; Huhtinen 1987; Schumacher 1979, 1993).

Descriptions of several species of Octospora from Estonia and Finland have been presented (Dietrich 1856; Dietrich 1859; Raitviir 1963; Benkert 1987; Kullman 1991, 1997). Four species were known earlier from Estonia: $O$. carbonicola (Boud.) Yei-Zeng Wang, O. humosa (Fr.: Fr.) Dennis, O. leucoloma Hedw.: Gray and $O$. tetraspora (Fuckel) Korf.

This paper presents a survey of the species of the genus Octospora in Finland and in Estonia. 


\section{Material and methods}

79 herbarium specimens of the genus Octospora from $\mathrm{H}$, OULU, TAA and TUR were studied.

In addition, fresh specimens were examined. For SEM these were fixed in $4 \%$ glutaraldehyde in a phosphate buffer ( $\mathrm{pH} 7$ ). Furter the specimens were moved, through a gradual ethanol series, into $100 \%$ ethanol, then they were critical-point dried, coated with a $20 \mathrm{~nm}$ layer of gold, and examined and photographed using a Tesla BS 301 scanning electron microscope.

Cross-sections of apothecia, with a thickness of $10-$ $40 \mu \mathrm{m}$, were prepared from fixed and dried apothecia with the freezing-microtome "Microm HM 500 OM". The working temperature was $-25^{\circ}$ to $-20^{\circ} \mathrm{C}$. The crosssections were photographed using a "Leitz" Labourlux microscope.

The fruitbodies were measured using the microscope "Amplival", and drawn by means of the drawing apparatus PA-6, (objective 40, immersion objective HI 100). A solution of cotton blue in lactophenol was used as the research medium.

The length $(\mathrm{L})$ and width $(\mathrm{W})$ of spores are presented in the following form: $\left(\mathrm{L}_{\min }\right) \overline{\mathrm{L}}_{\min }-\overline{\mathrm{L}}_{\max }\left(\mathrm{L}_{\max }\right) \times\left(\mathrm{W}_{\min }\right) \hat{\mathrm{W}}_{\min }$ $-\hat{\mathrm{W}}_{\max }\left(\mathrm{W}_{\max }\right) \mu \mathrm{m}$, where $\hat{\mathrm{L}}_{\min }, \overline{\mathrm{L}}_{\max }, \hat{\mathrm{W}}_{\min }$ and $\hat{\mathrm{W}}_{\max }$ denote the minimum and maximum mean values of 20 spore lengths and widths of specimens, and $\mathrm{L}_{\min }, \mathrm{W}_{\min }$ and $\mathrm{L}_{\max }$, $\mathrm{W}_{\max }$, the minimum and maximum absolute values of length and width, respectively. The shape of ascospores is presented as an average ratio of spore length to spore width (Q).

\section{List of species}

1. Octospora alpestris (Sommerf.) Dennis \& Itzerott, Kew Bull. 28:10. 1973. - Figs. 6, 17, $18 \mathrm{~A}-\mathrm{B}$

Peziza alpestris Sommerf., Suppl. Florae Lapponicae: 290. 1826.

Peziza carneola Saut., Mitt. Ges. Salzburger Landesk. 18(2):7. 1878

Humaria carneola (Saut.) Sacc., Syll. Fungorum 8: 123. 1889.

Octospora carneola (Saut.) Dennis, British Cup Fungi: 34. 1960 .

Apothecium at first cupulate, later discoid, up to $4 \mathrm{~mm}$ in diam, concave, hymenium yellowish-orange when dry. Outside paler, base tomentose. Margin paler, distinct, dentate, fimbriate.

Receptacle two-layered, with ectal excipulum, 40-65 mm thick, consisting of textura intricata, hyphae 6-10 (30) $\mu \mathrm{m}$ in diam., thickwalled, wall 1.5-2 $\mu \mathrm{m}$ thick. Medullary excipulum 420-960 $\mu \mathrm{m}$ thick, consisting of $t$. intrica- ta, hyphae 7-21 $\mu \mathrm{m}$ in diam., thin-walled, wall up to $1 \mu \mathrm{m}$ thick. In bigger apothecia vertical orientation of hyphae may occur in the central part of medullary excipulum, analogous to $t$. porrecta. Marginal excipulum consists of $t$. porrecta, hyphae more regularly arranged, running parallel with the surface of receptacle, 7$21 \mu \mathrm{m}$ in diam, obtuse end cells of long cylindrical hyphae form the margin. Hypothecium 50-60 $\mu \mathrm{m}$ thick, consisting of $t$. intricata, hyphae 3-5 $\mu \mathrm{m}$ in diam. Hymenium 145-190 $\mu \mathrm{m}$ thick.

Mature asci with 4 matured and 4 aborted ascospores. Immature asci contain 8 semimature ascospores. Ascospores cylindrical, hyaline, with one or two guttulae, (12.6) 13.4-14.4 (15.8) $\times(7.2) 7.9-8.5(9.1) \mu \mathrm{m}$, excluding ornamentation, $\mathrm{Q}=1.7$. Ornamentation consists of warts of an irregular size and shape. Paraphyses straight or slightly curved, up to $3-5 \mu \mathrm{m}$ in diam at the apex.

$O$. alpestris grows exclusively on leaves and stems of the moss of the genus Tetraplodon associated with animal remains. T. angustatus in 9 specimens and T. mnioides in in 9 specimens. Specimens collected between 23 July and 4 October.

Specimens examined: Finland. Varsinais-Suomi: Nauvo, 662:20, 1994 Huhtinen (TUR); Oulun Pohjanmaa: Haukipudas, 7236:446, 1967 Ulvinen (OULU); Pudasjärvi, 72871:5170, 1971 M. Ohenoja (OULU); Koillismaa: Kuusamo, 7366:604, 1977 Ulvinen (OULU); 7366:602, 1974 Ulvinen (OULU); 7366:602, $1983 \mathrm{E}$. Ohenoja (OULU); Posio, 7323:554, 1979 Ulvinen (OULU); Sompion Lappi: Savukoski, 7484:558, 1975 Vuokko (OULU); Inarin Lappi: Inari, 7645:440, 1965 Mäkinen (TUR); 7675:453, 1965 Mäkinen (TUR); 7653:449, 1965 Mäkinen (TUR); 760:55, 1968 Mäkinen (TUR); Utsjoki, 774:49, 1961 Kallio; 7742:499, 1964 Mäkinen (TUR); 7738:501, 1965 Mäkinen (TUR).

Discussion. Octospora alpestris is easily distinguishable from the other species of the genus due to four aborted spores in the eight-spored ascus.

Excipular characters showed notable variability. In one specimen the diameter of hyphae in medullary excipulum was $7-10 \mu \mathrm{m}$, and in another specimen, $15-20 \mu \mathrm{m}$. Variation of the same degree has been found also in hyphae of ectal excipulum and margin (see Figs. 17C-D, $18 \mathrm{~A}-\mathrm{B})$. 
2. Octospora axillaris (Nees : Pers.) M.M. Moser, Gams, Kleine Kryptogamenflora 2A: 110. 1963. - Fig. 10

Peziza axillaris Nees : Pers., Mycologia Europaea I: 314. 1822.

Leucoloma axillaris (Nees : Pers.) Fuckel, Jahrb. Nassauischen Vereins Naturk. 23-24:318. 1870.

Apothecium minute, discoid, up to $1.5 \mathrm{~mm}$ in diameter, reddish-orange when dried. Outside whitish, tomentose, margin indistinct.

Receptacle two-layered, with ectal excipulum, 30-55 $\mu \mathrm{m}$ thick, consisting of $t$. intricata, hyphae $8-14 \mu \mathrm{m}$ in diam, walls $1.5-2 \mu \mathrm{m}$ thick. Medullary excipulum up to $130 \mu \mathrm{m}$ thick, consisting of $t$. intricata, hyphae 6-14 $\mu \mathrm{m}$ in diam, wall up to $1 \mu \mathrm{m}$ thick. Marginal excipulum con- sists of $t$. porrecta, hyphae more regularly arranged, monilioid, running parallel with the surface of receptacle, 7-19 $\mu \mathrm{m}$ in diam, with obtuse, cylindrical end cells. Hypothecium consisting of $t$. intricata, hyphae 30-40 $\mu \mathrm{m}$ thick. Hymenium 225-260 $\mu$ m thick.

Asci with 8 ascospores. Ascospores ellipsoid to subfusoid, hyaline, uniguttulate with some small guttulae, smooth, (20.3) $23.0(27.1) \times(9.5)$ 10.5 (12.6) $\mu \mathrm{m}, \mathrm{Q}=2.2$. Paraphyses straight, diam at the apex up to $3-6 \mu \mathrm{m}$.

$O$. axillaris grows on calcium-rich soil amongst mosses Bryum argenteum and Bryum sp. and Ceratodon purpureus.

Specimen examined: Estonia. Tartumaa: Voldi, 6.IX.1993 Kullman (TAA 117949a).
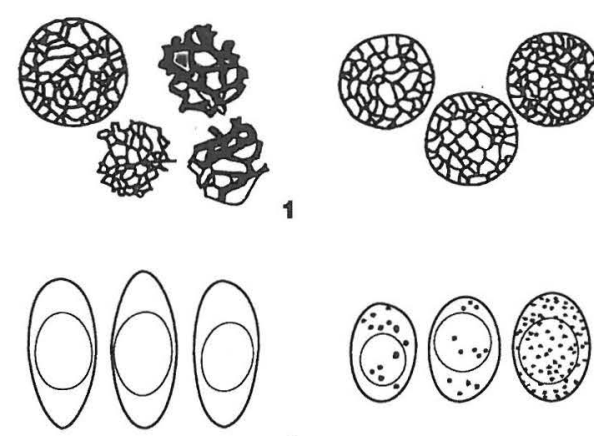

4
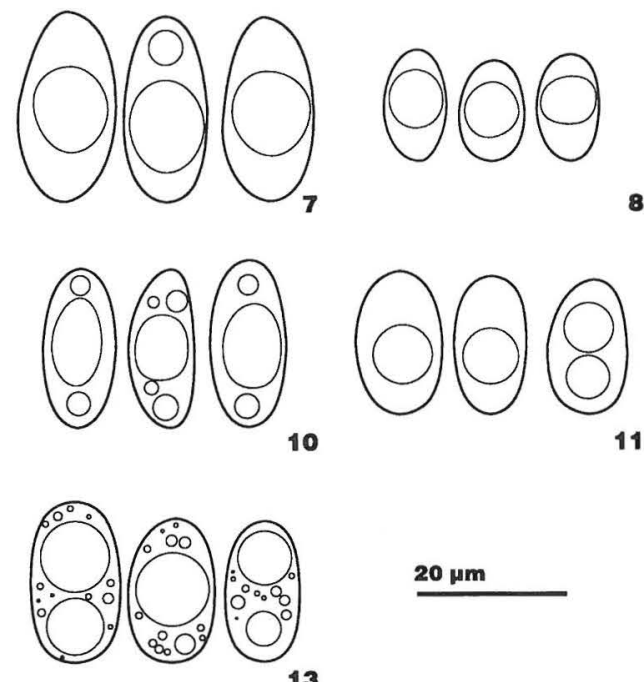

$20 \mu \mathrm{m}$
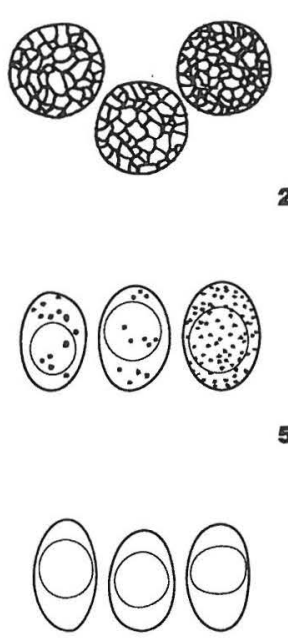

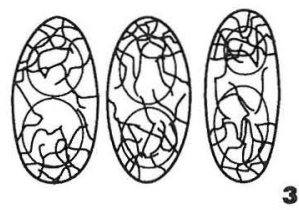

3
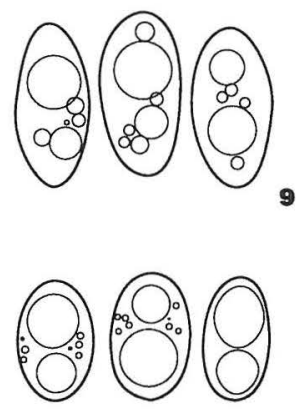

12

Figs. 1-13. Spores. - 1: Octospora seaveri. - 2: O. carbonicola. - 3: O. borealis. - 4: O. leucoloma. - 5: O. melina. - 6: O. alpestris. - 7: O. sp. (TAA 118091). - 8: O. rustica. - 9: O. tetraspora. - 10: O. axillaris. - 11: $O$. crosslandii. - 12: O. rubens. - 13: O. humosa. 

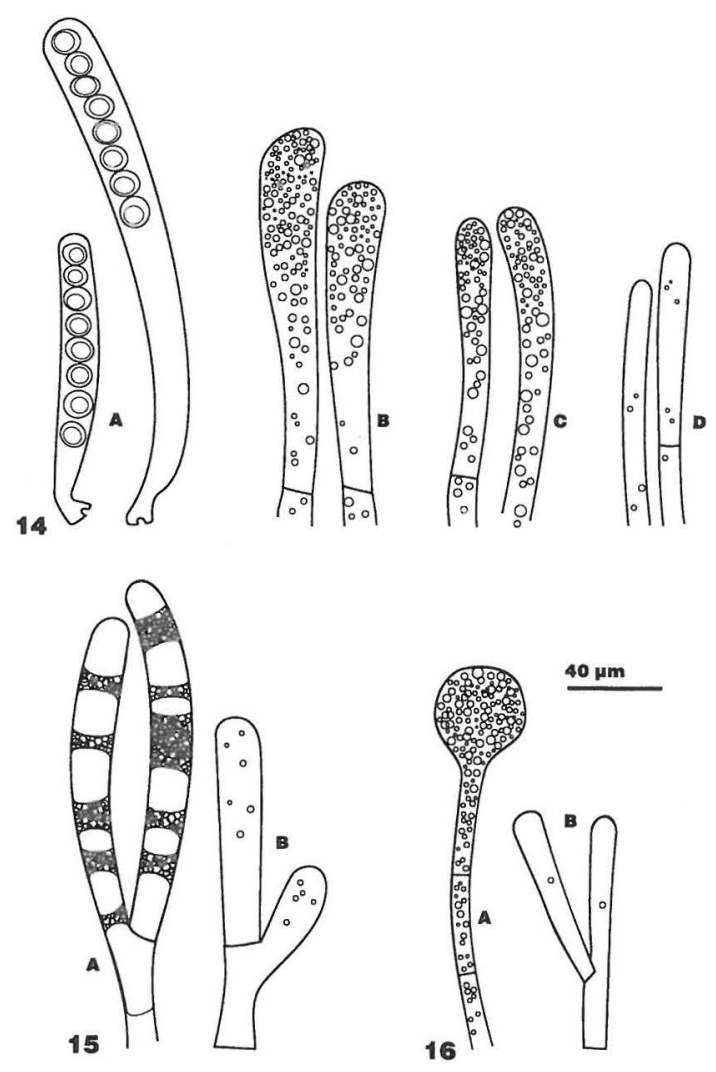

Fig 14A-D. Octospora wrightii: A) living and mature asci from the same apothecium in water, B) living paraphyses after being exposed for $2 \mathrm{~h}$ to high humidity, C) living paraphyses immediately after collecting, D) paraphyses after herbarization. - 15A-B. O. humosa: A) living paraphyse in water, B) herbarized paraphyse in water. -16 A-B. O. rustica: A) living paraphyse in water, B) herbarized paraphyse from the same specimen in water.

Discussion. O. axillaris is distinguishable from the other species of the genus by the shape and size of its spores. O. axillaris has clearly longer spores. According to literature, $O$. axillaris is known to occur with mosses Phascum cuspidatum and Pottia lanceolata (Itzerott 1981), and Enthostodon fascicularis, Pottia rufescens, Barbula unguiculata and Bryum erythrocarpum (Caillet \& Moyne 1987).
3. Octospora borealis (Eckblad) Caillet \& Moyne, Bull. Soc. Mycol. France 3:179-226. 1987. - Figs. 3, 18C-D, 19A-B

Leucoscypha borealis Eckblad, Nytt. Mag. Bot. 15:5253. 1968.

Apothecium immersed, cupulate or discoid, concave, 3-6 $\mathrm{mm}$ in diam, hymenium orange when dried. Outside paler, slightly tomentose, base covered with dense, tomentose mycelium which anchors apothecium to the substratum.

Receptacle two-layered, diam of hyphae in ectal excipulum smaller and walls thicker than in medullary excipulum. Ectal excipulum 70$160 \mu \mathrm{m}$ thick, consisting of $t$. intricata, hyphae 6-22 $\mu \mathrm{m}$ in diam, wall $2.5-5.5 \mu \mathrm{m}$ thick. Medullary excipulum up to $480 \mu \mathrm{m}$ thick, consisting of $t$. porrecta, hyphae parallel, 8-32 $\mu \mathrm{m}$ in diam, thick-walled, wall up to $3 \mu \mathrm{m}$ thick. Margin consists of $t$. porrecta, hyphae $8-16 \mu \mathrm{m}$ in diam. Hypothecium 65-80 $\mu \mathrm{m}$ thick, consisting of $t$. intricata, hyphae $2.5-4 \mu \mathrm{m}$ in diameter. Hymenium 200-270 $\mu$ m thick.

Asci with 8 ascospores. Ascospores ellipsoid, hyaline, with two guttulae, (18.3) 19.1-22.1 (23.6) $\times$ (9.5) 10.4-11.6 (12.0) $\mu \mathrm{m}$, excluding ornamentation, $\mathrm{Q}=1.9-2.1$. Ornamentation consists of fine ridges forming incomplete reticulum which is denser on the ends of ascospore. Paraphyses clavate, straight or slightly curved, diam at the apex 5-8 $\mu \mathrm{m}$.

$O$. borealis grows on sandy soil with Blepharostoma sp., Bryum sp., Calliergonella cuspidata, Ceratodon purpureus, Ditrichum sp., Mniobryum wahlenbergii, Pohlia sp., Polytrichum hyperboreum, Rhizomnium sp. and Sphagnum sp.

Specimens collected between 28 July and 4 August.

Specimens examined: Finland. Oulun Pohjanmaa: Pudasjärvi, 72742:5157, M. Ohenoja (OULU); Sompion Lappi: Pelkosenniemi, 7450:510, 1985 E. Ohenoja (OULU); Inarin Lappi: Utsjoki, 7742:499, 1963 Mäkinen (TUR); 7759:501, 1965 Mäkinen (TUR); 7709:509, 1981 Kalamees (TAA 121985).

Discussion. O. borealis is similar to $O$. humosa (size and shape of spores, shape of apotecium) but differs clearly from the smooth-spored $O$. humosa by the fine ornamentation of spores. The ornamentation can be seen at higher magnification (with an oil immersion objective) when stained with $\mathrm{CB}$. 

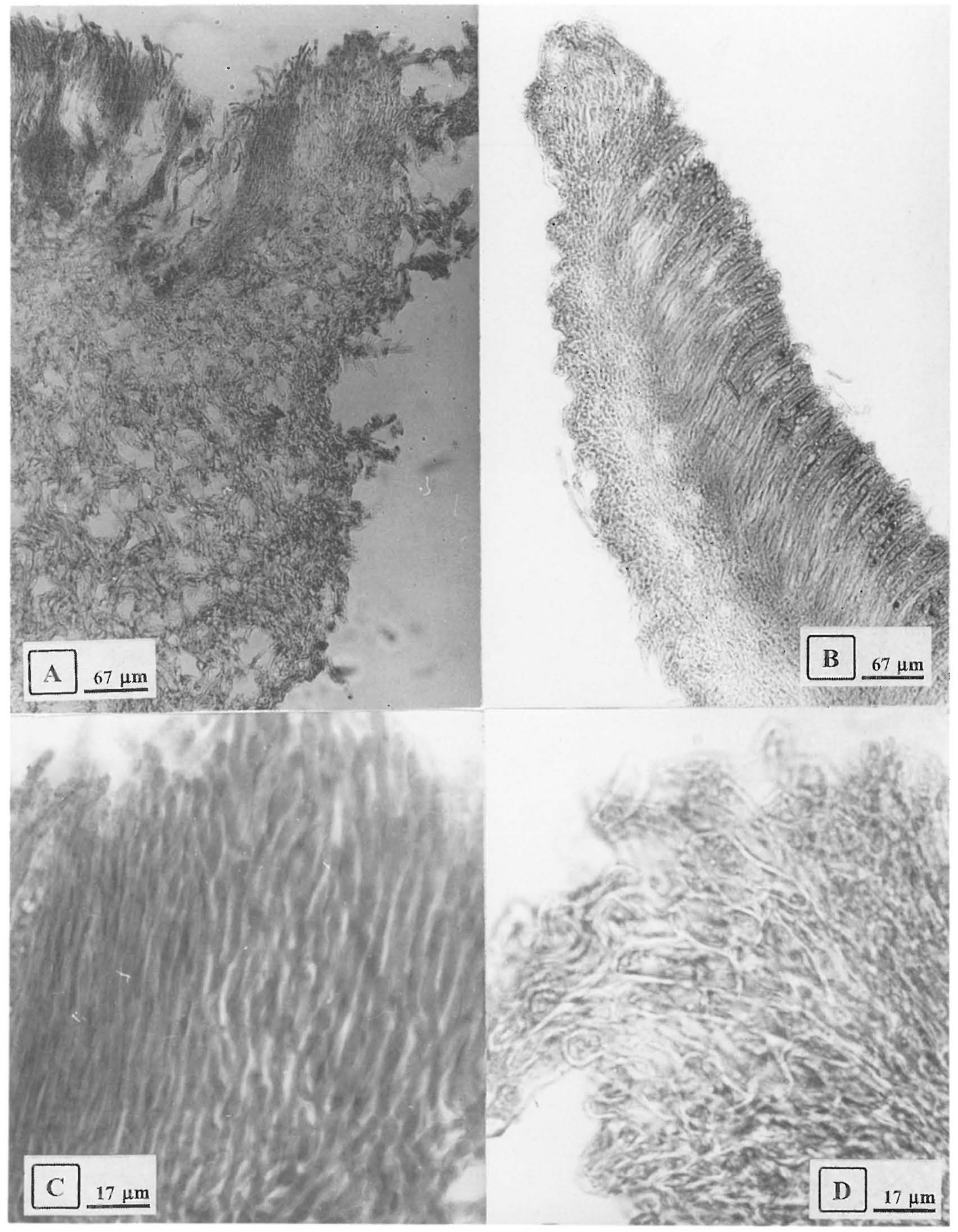

Fig. 17. Octospora alpestris: A) margin of cup-shaped apothecium (Ulvinen, 30.VIII.1977), B) margin of disc-shaped apothecium (Mäkinen, 22.VIII.1964). - C-D. Margin, t. porrecta: C) (Kallio, 18.VIII.1961), D) (Mäkinen, 22.VIII.1964). 


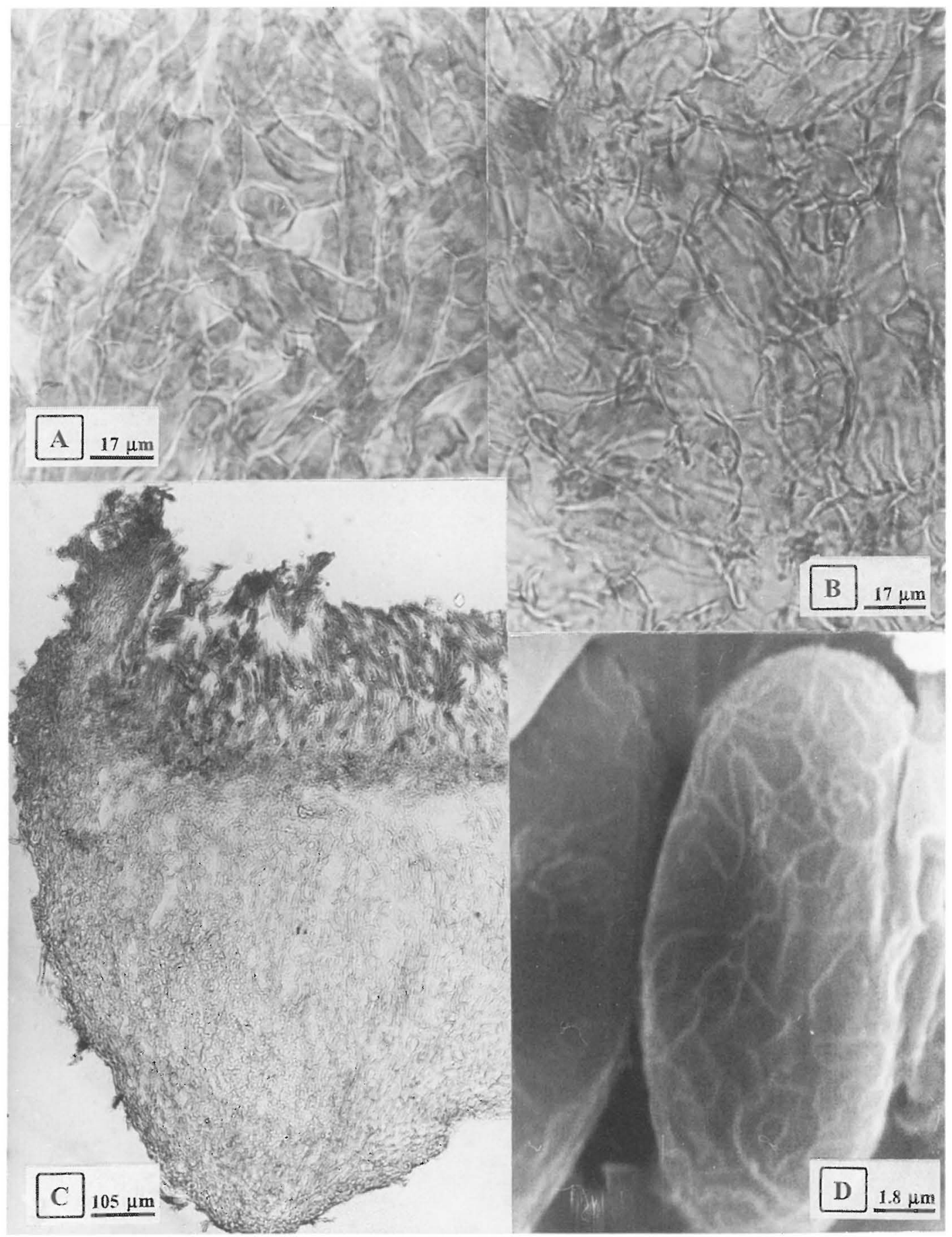

Fig. 18 A-B. Octospora alpestris, medulla, t. intricata: A) (Kallio, 18.VIII.1961), B) (Mäkinen, 1.VI.1965). - C-D. O. borealis: C) cup-shaped apothecium (Ohenoja, 6.VIII.1991), D) spore (TAA 121985). 




Fig. 19 A-B. Octospora borealis: A) margin of disc-shaped apothecium (Ohenoja, 10.VIII.1985), B) ectal excipulum, t. intricata (Ohenoja, 6.VIII.1991). - C-D. O. humosa: C) cross-section of apothecium (Heinonen, 22-88), D) asci and paraphyses from a living fruitbody in water (TAA 135658). 
4. Octospora carbonicola (Boud.) Yei-Zeng Wang, Special Publ. Natl. Mus. Nat. Sci. Taiwan 4:41. 1992. - Fig. 2

Lamprospora carbonicola Boud., Hist. Class. Discom.: 68. 1907.

Lamprospora polytrichi (Schum.) Le Gal, Bull. Soc. Mycol. France 56:39. 1940.

Asci with 8 ascospores. Ascospores globose, uniguttulate, with fine ornamentation consisting of ridges which form a complete reticulum, ridges up to $0.6 \mu \mathrm{m}$ in height, (11.3) 12.0 (12.6) $\mu \mathrm{m}$ excluding ornamentation.

Specimen examined: Estonia: Tartumaa: Lemmatsi, 7.X.1989 Kullman (TAA 117313).

Discussion. Because of insufficient material, Octospora carbonicola is described only by ascospore characters. Descriptions are based on a five-year-old slide.

This specimen has smaller ascospores than reported for this species in literature: $13-15 \mu \mathrm{m}$ (Benkert 1987), 14-16 $\mu \mathrm{m}$ (Wang \& Kimbrough 1992), but ornamentation is similar to that described in literature.

$O$. carbonicola is similar to many species by globose, reticulate spores, but has a specific, finer and denser reticulum.

5. Octospora crosslandii (Dennis \& Itzerott) Benkert, Feddes Repert. 87(9-10):618. 1976. Fig. 11

Octospora leucoloma var. crosslandii Dennis \& Itzerott, Kew Bull. 28:15. 1973.

Apothecium minute, at first cupulate, with thick, raised margin, later flattened, with indistinct margin, $1-1.5 \mathrm{~mm}$ in diam, orange when dried. Outside concolorous, glabrous.

Receptacle two-layered, walls of hyphae thicker in ectal excipulum than in medullary excipulum. Ectal excipulum 30-50 $\mu \mathrm{m}$ thick, consisting of $t$. intricata, hyphae $10-20 \mu \mathrm{m}$ in diam, wall $1.5-2 \mu \mathrm{m}$ thick. Medullary excipulum 220-250 $\mu \mathrm{m}$ thick, consisting of $t$. intrica$t a$, hyphae $5-10 \mu \mathrm{m}$ in diam, wall up to $1 \mu \mathrm{m}$ thick. Hyphae are reoriented towards the margin of receptacle, their cells becoming longer and more regularly arranged, running parallel with the surface of receptacle, 5-11 $\mu \mathrm{m}$ in diam at obtuse end cells of long, cylindrical hyphae which form the margin. Hypothecium consisting of $t$. intricata, up to $50 \mu \mathrm{m}$ thick, hyphae 3-6 $\mu \mathrm{m}$ in diam. Hymenium 220-260 $\mu$ m thick.

Asci with 8 ascospores. Ascospores asymmetrical, ellipsoid, hyaline, with one or two guttulae, smooth, (14.5) 20.6 (22.1) $\times(10.7)$ 11.6 (12.6) $\mu \mathrm{m}, \mathrm{Q}=1.8$. Paraphyses clavate, straight, diam at the apex 6-12 $\mu \mathrm{m}$.

$O$. crosslandii grows on stems and leaves of Tortella inclinata.

Specimen examined: Estonia. Saaremaa: Tagarand, UTM 0617, 12.IX.1993, Jakobson (TAA 135634).

Discussion. O. crosslandii is similar to O. leucoloma but differs from this species by broader spores. Some ecological differences can also be detected. O. leucoloma grows mostly with moss Bryum but $O$. crosslandii has never been found together with this moss species.

6. Octospora humosa (Fr. : Fr.) Dennis, British Cup Fungi: 33. 1960. - Fig. 13, 15, 19C-D, 20

Peziza humosa Fr.:Fr., Mycologia Europaea I: 297.1822 et Fr., Syst. Myc. 2:71. 1822.

Humaria humosa (Fr.: Fr.) Quél., Enchiridion Fungorum: 289. 1886.

Apothecium immersed, at first cupulate, later discoid, up to $10 \mathrm{~mm}$ in diam. Hymenium concave, grayish-orange to orange when dried. Outside paler, tomentose, covered with dense mycelium which anchors apothecium to the substratum. Margin raised, dentate, fimbriate.

Receptacle two-layered, walls of hyphae in ectal excipulum thicker than in medullary excipulum. Ectal excipulum 50-80 $\mu \mathrm{m}$ thick, consisting of $t$. intricata, hyphae 10-24 $\mu \mathrm{m}$ in diam, wall 2.5-3 $\mu \mathrm{m}$ thick. Medullary excipulum 550-1090 $\mu \mathrm{m}$ thick, consisting of $t$. porrecta, hyphae $13-24 \mu \mathrm{m}$ in diam, wall up to 1.5 $\mu \mathrm{m}$ thick. Margin consists of $t$. porrecta, hyphae 6-21 $\mu \mathrm{m}$ in diam. Hypothecium up to 55 $\mu \mathrm{m}$ thick, consisting of $t$. intricata, hyphae 3-5 $\mu \mathrm{m}$ in diam. Hymenium $160-260 \mu \mathrm{m}$ thick.

Asci with 8 ascospores. Ascospores cylindrical, with rounded ends, hyaline, with one or two big and many small guttulae, smooth, (17.0) 18.5-23.1 (25.9) × (9.5) 10.5-13.2 (14.5) $\mu \mathrm{m}$, $\mathrm{Q}=1.57-1.92$. Paraphyses clavate, straight or slightly curved, diam at the apex 3-8 $\mu \mathrm{m}$. 


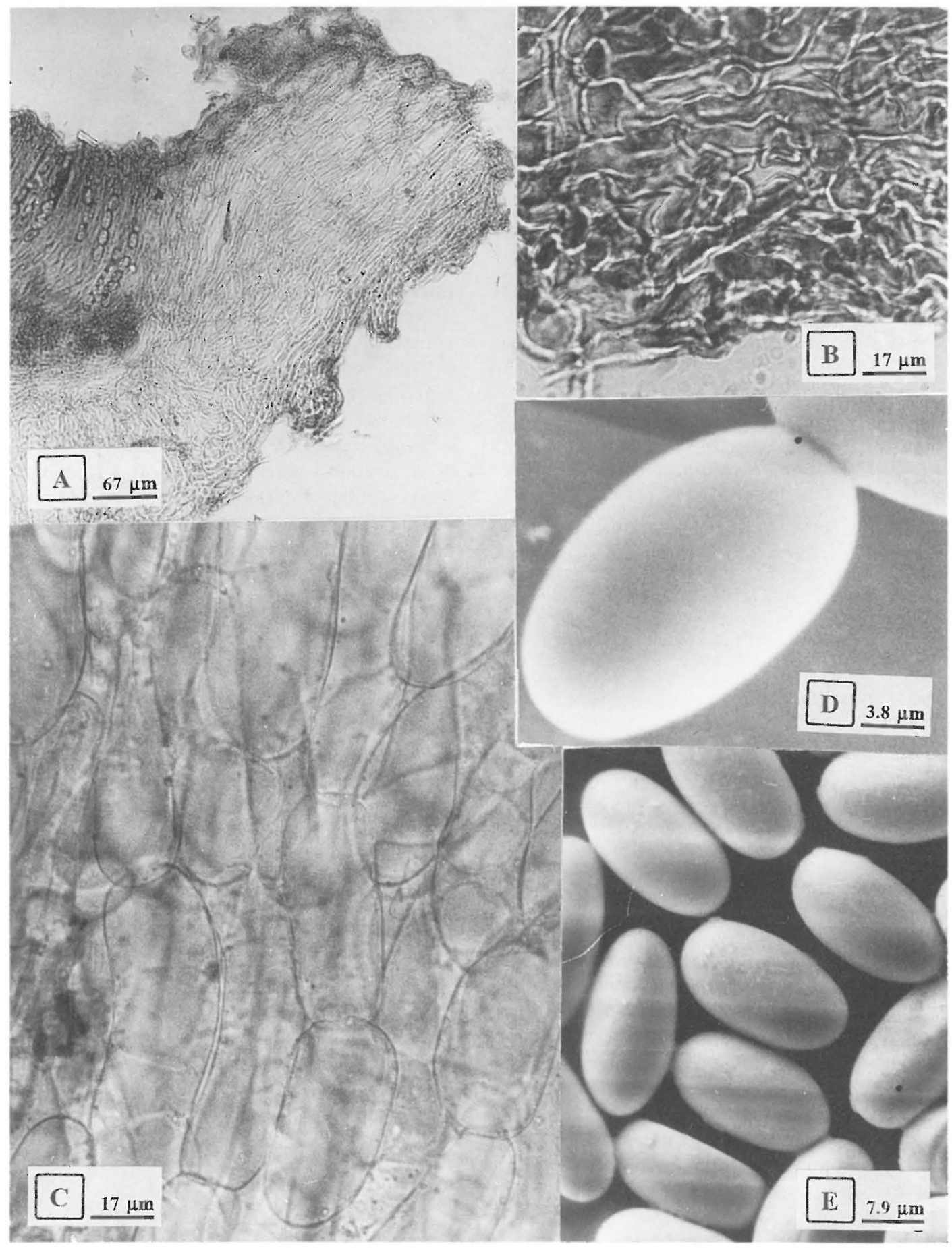

Fig. 20. Octospora humosa. - A) Margin, t. porrecta (TAA 135658), B) ectal excipulum, t. intricata (Mäkinen, 68-1497), C) medulla. t. porrecta, living hyphae in water (TAA 135658), D) spore (TAA 135672), E) spores (TAA $135658)$. 
Grows amongst mosses Bryum sp. (in one specimen), Calliergon sp. (in one specimen), Ceratodon purpureus (in 16 specimens), Dicranella sp. (in 5 specimens), Pogonatum urnigerum (in one specimen), Polytrichum hyperboreum (in 3 specimens), P. juniperum (in 6 specimens), $P$. piliferum (in 6 specimens), $P$. swartzii (in one specimen), Polytrichum sp. (in one specimen), Pohlia sp. (in 10 specimens), Oligotrichum sp. (in one specimen).

Specimens collected between 20 July and 20 October.

Specimens examined: Estonia. Põlvamaa: Taevaskoja, 1985 Kalamees (TAA 124501); 1987, Kalamees (TAA 125706); Viljandimaa: Kõpu,1993 Kullman (TAA 117924). Finland. Varsinais-Suomi: Pöytyä, Kontolanrahka, 6478:269, 1994 Jakobson (TAA 135658); Kemiö, 6688:271, 1966 Kankainen (TUR); Koski, 672703:28960, 1988 Heinonen 22-88 (TUR); Nauvo, 6691:221, 1994 Jakobson (TAA 135672); Tenhola, 6665:278, 1987 Saarenoksa $16987(\mathrm{H})$; Etelä-Häme: Somerniemi, 6725:491, 1968 Mäkinen 68-1479 (TUR); Pohjois-Häme: Jyväskylä, 1978 Harmaja (H); PohjoisSavo: Kuopio, 6985:547, 1983 Vauras 1567 (TUR); Keski-Pohjanmaa: Pulkkila, 1979 Harmaja (H); Oulun Pohjanmaa: Oulu, 7210:427, 1965 Ulvinen (OULU); Pudasjärvi, 72570:5181, 1991 M. Ohenoja (OULU); PeräPohjanmaa: Ylitornio, 7392:402, 1976 Kaakinen \& Karjalahti (OULU); Koillismaa: Posio, 1969 Ulvinen (OULU); Enontekiön Lappi: Enontekiö, 1979 Harmaja (H); 763:36, 1971 E. Ohenoja (OULU); Inarin Lappi: Inari, 7608:520, 1965 Pohjola (TUR); 1972 Mäkinen 72-639 (TUR); 7612:518, 1968 Kankainen (TUR); Utsjoki, 770:50, 1962 Kallio (TUR); 7738:501, 1965 Ulvinen (OULU); 7741:501, 1965 Ulvinen (OULU); 7742:499, 1962 Suominen (TUR); 7741:500, Mäkinen (TUR); 7742:500, 1965 Mäkinen (TUR); 770:50, 1964 Hulkko (TUR); 7759:501, 1962 Kallio (TUR); 7742:500, 1968 Kankainen (TUR); 77420:5004, 1963 Mäkinen (TUR).

Discussion. Paraphyses studied in living state in water contained many small orange pigment guttulae among regularly distributed hyaline guttulae forming perpendicular stripes. When the same specimen was studied after herbarization, no hyaline guttulae were found, while only some orange guttulae were present (Fig. 15.).

A significant difference in thickness has been detected between the older (central, 260 $\mu \mathrm{m})$ and younger (marginal, $160 \mu \mathrm{m}$ ) parts of the hymenium. Accordingly, the thickness of the hymenium (including ascus length) depends on the age of the apothecium.

7. Octospora leucoloma Hedw.: Gray, Natural Arrangement of British Plants I:667. 1821. Figs. 4, 21, 22A-C, 31A
Peziza leucoloma (Hedw.: Gray) Pers., Mycologia Europaea I: 296.1822.

Humaria leucoloma (Hedw.: Gray) Seaver, The North American Cup-Fungi (Operculates): 129. 1928.

Apothecium minute, immersed, discoid, up to 2 $\mathrm{mm}$ in diam, orange when dried. Outside paler, tomentose, totally covered with mycelium which anchors apothecium to the substratum. Margin indistinct, fimbriate.

Receptacle two-layered, walls of hyphae thicker in ectal excipulum than in medullary excipulum. Ectal excipulum 50-70 $\mu$ m thick, consisting of $t$. intricata, hyphae 7-10 (24) $\mu \mathrm{m}$ in diam, walls $2-3 \mu \mathrm{m}$ thick. Medullary excipulum 50-200 $\mu \mathrm{m}$ thick, t. intricata, hyphae 6-16 $\mu \mathrm{m}$ in diam, wall 1-2 $\mu \mathrm{m}$ thick. Hyphae are reoriented towards the margin of receptacle, forming $t$. porrecta, their cells becoming longer and more regularly arranged, running parallel with the surface of receptacle, 5-11 $\mu \mathrm{m}$ in diam at obtuse end cells of hyphae which form the margin. Hypothecium 50-60 $\mu \mathrm{m}$ thick, consisting of $t$. intricata, hyphae 3-5 $\mu \mathrm{m}$ in diam. Hymenium 160-200 $\mu$ m thick.

Asci with 8 ascospores. Ascospores asymmetrical, ellipsoid to subfusoid, hyaline, with one or occasionally two guttulae, smooth 19.2 $20.8(21.7) \times(8.5)$ 9.5-9.9 (10.4) $\mu \mathrm{m}, \mathrm{Q}=1.9$ 2.2. Paraphyses clavate, straight or slightly curved, diam at the apex 4-5 $\mu \mathrm{m}$.

Grows on calcium rich soil with mosses.

Specimens collected between 25 July and 4 October.

Specimens examined: Estonia. Tartu: Aardla, on Bryum argenteum, Ditrichum sp. and Phascum sp., 1991 Kullman (TAA 117657); Lemmatsi, 1989 Kullman (TAA 117312). Finland. Varsinais-Suomi: Särkisalo, on Bryum sp., and Dicranella varia, 6672:270, 1994 Jakobson (TAA 135664a); Satakunta: Siikainen, on Barbula convoluta, Bryum sp. and Leptobryum pyriforme 6867:222, 1990 Vauras \& Huhtinen (TUR).

8. Octospora maireana (Seaver) Yei-Zeng Wang, Special. Publ. Natl. Mus. Nat. Sci. Taiwan 4:41. 1992. - Figs. 22D, 23, 24A-B. Description see in Kullman (1997).

9. Octospora melina (Velen.) Dennis \& Itzerott, Kew Bull., 28:17. 1973. - Figs. 5, 24C-D, $25 \mathrm{~A}$

Humaria melina Velen., Monogr. Discom. Bohemiae: 325. 1934. 


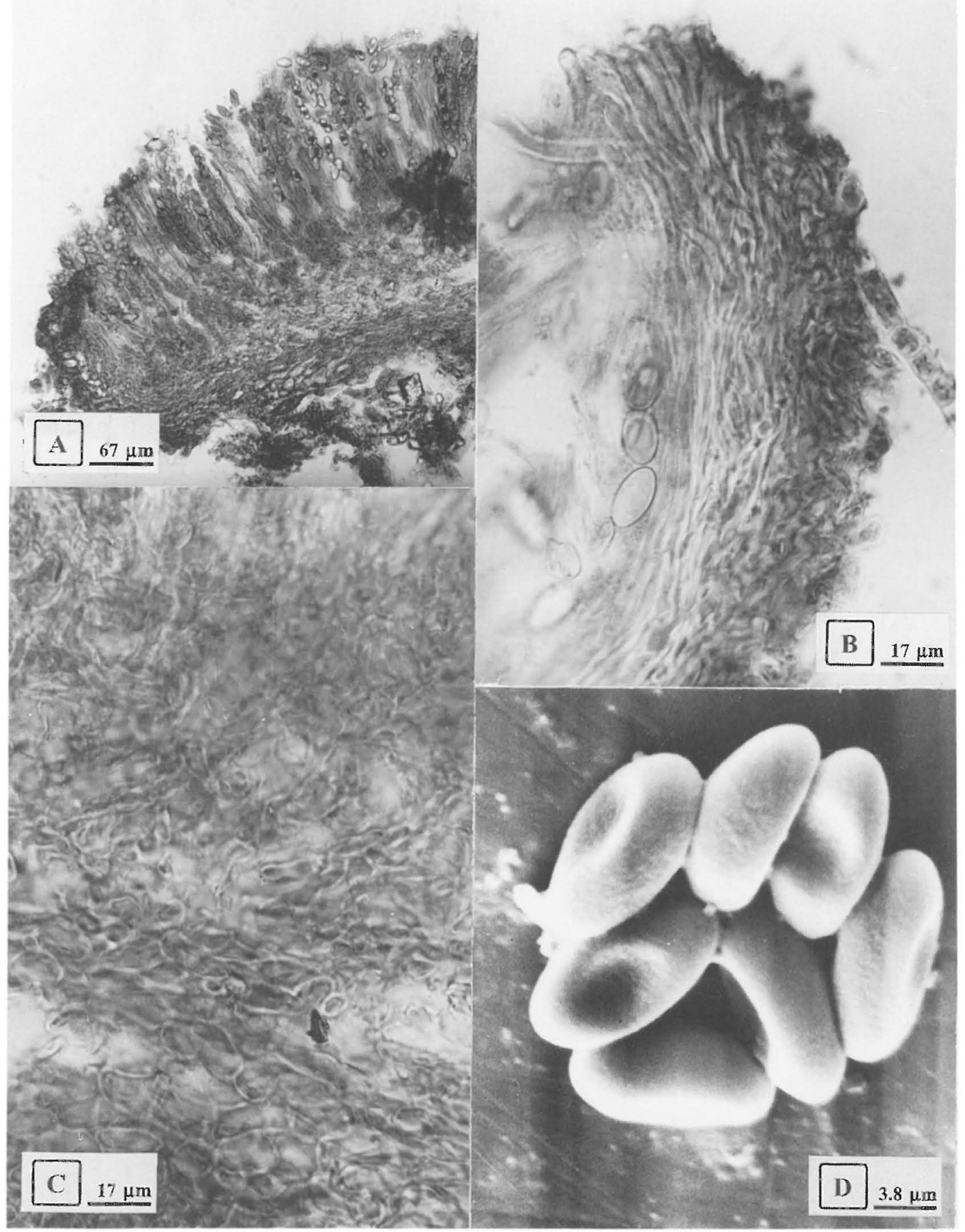

Fig. 21. Octospora leucoloma. - A) Cross-section of apothecium, B) margin, $t$. porrecta, C) ectal excipulum, medulla and hypothecium, $t$. intricata (TAA 117657), D) spores (TAA 117312). 


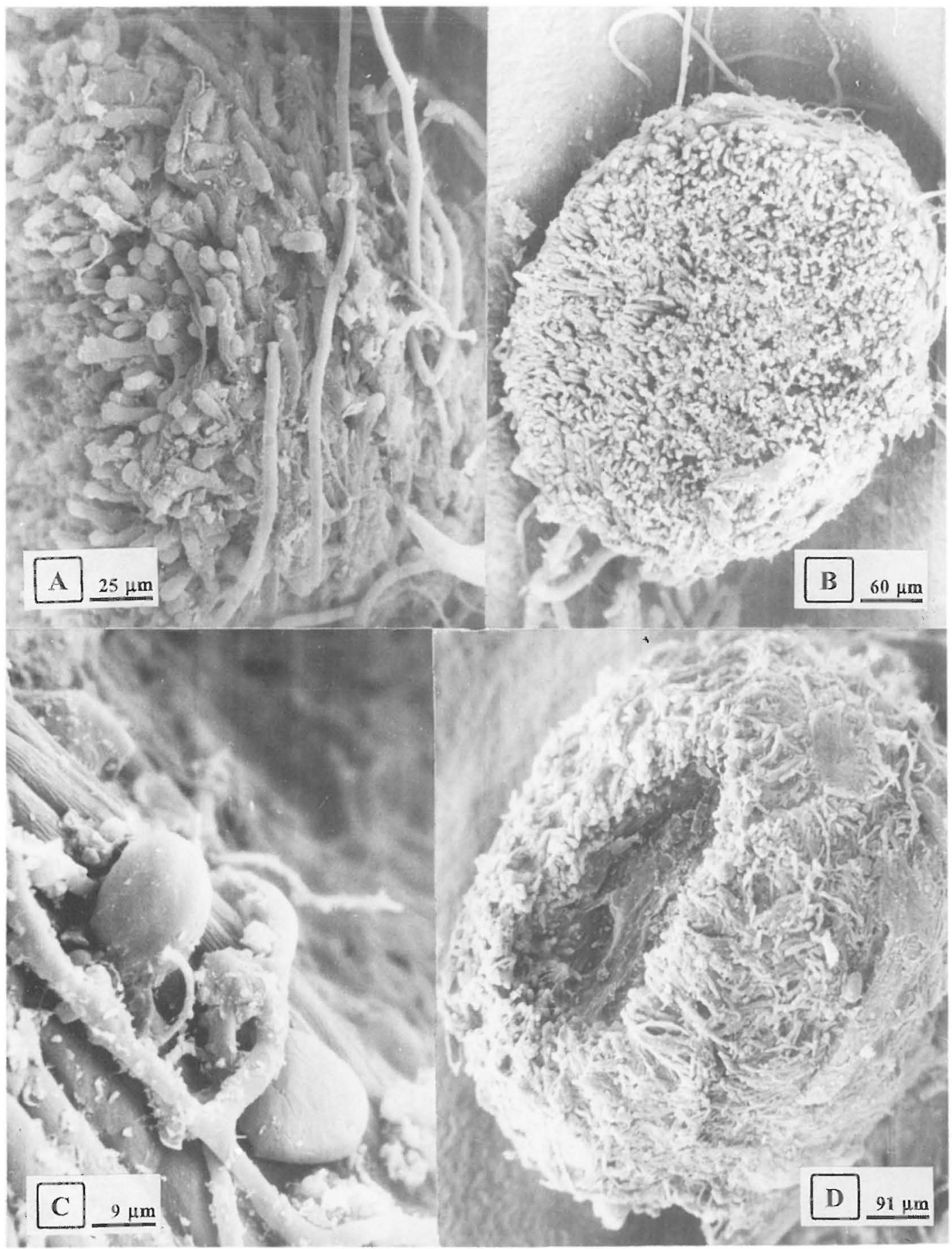

Fig. 22A-C. Octospora leucoloma. - A) Margin, $t$. porrecta (TAA 117657), B) fruitbody (TAA 117657), C) spores and hyphae on moss leaf (TAA 117657). - D. O. maireana: fruitbody (TAA 117649). 


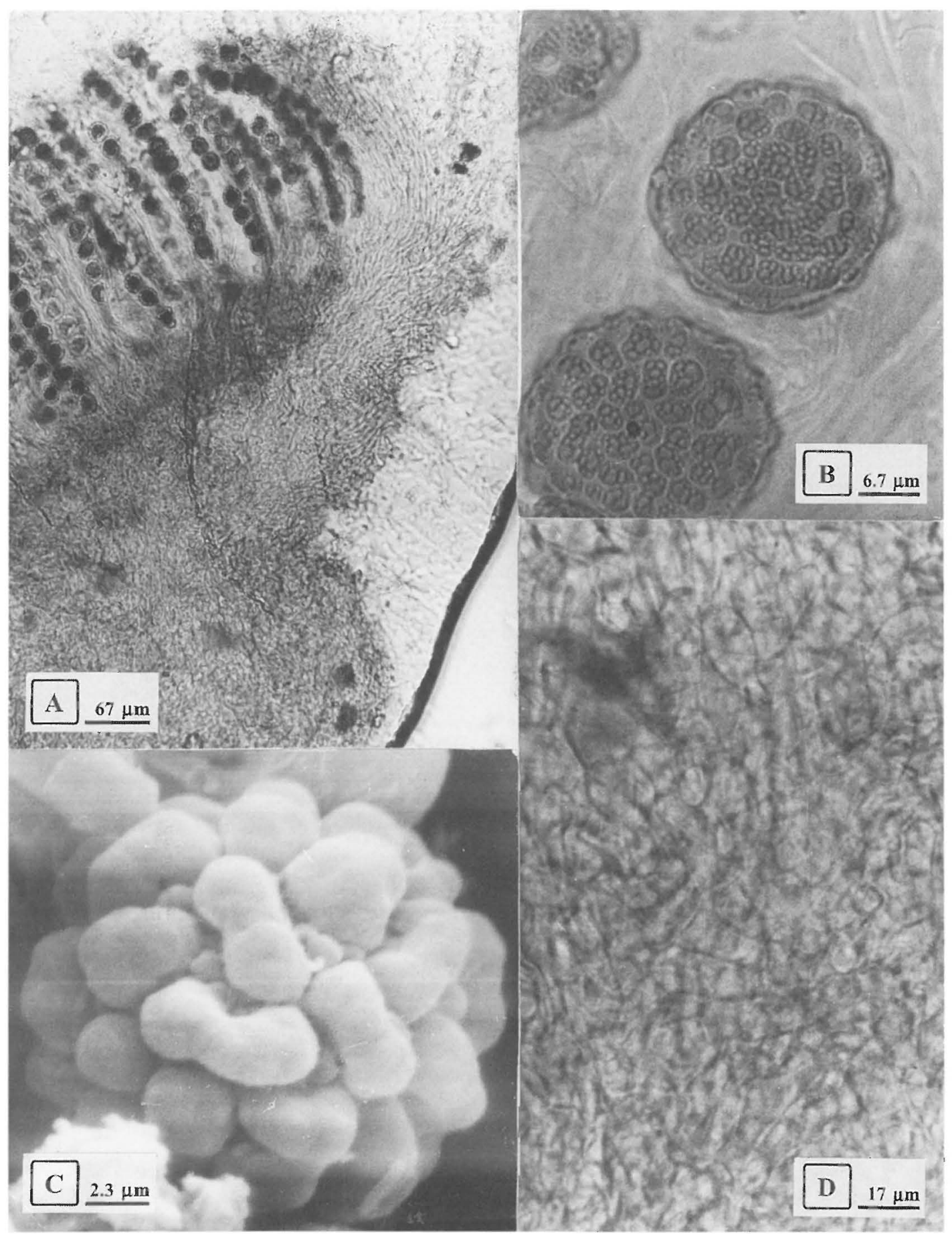

Fig. 23. Octospora maireana. - A) Cross-section, B) spores (F.J. Seaver 29.X.1913, isotype), C) spore (TAA 117649), D) medulla, $t$. intricata (isotype). 


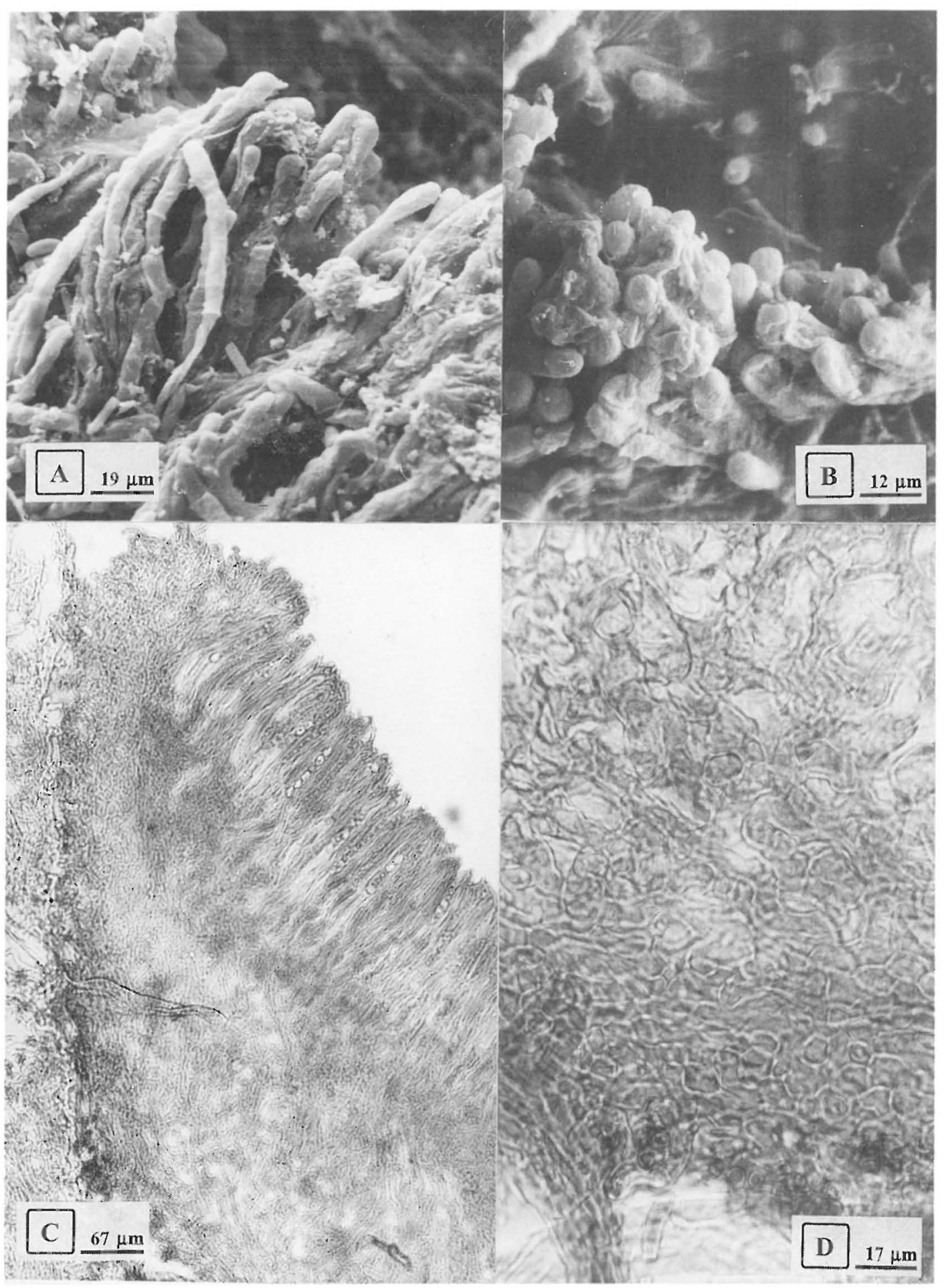

Fig. 24 A-B. Octospora maireana: A) margin, t. porrecta, B) margin (TAA 117649). - C-D. O. melina: C) crosssection of apothecium, D) ectal excipulum, t. intricata (Alho \& Alava, 9.X.1969). 


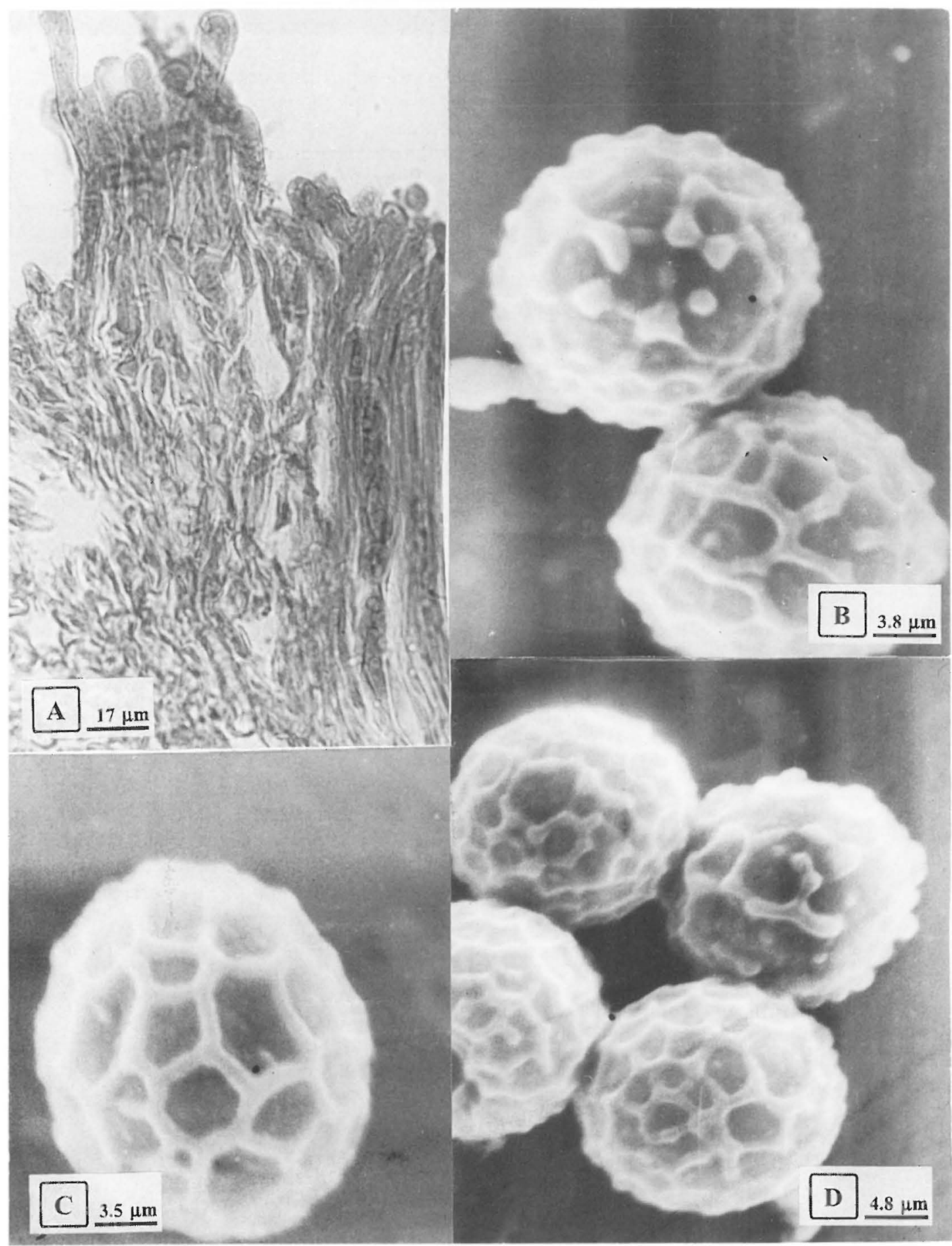

Fig. 25 A. Octospora melina: margin, t. porrecta (Alho \& Alava, 9.X.1969). - B-D. O. miniata: different ornamentation of spores from the same fruitbody (TAA 135663). 
Apothecium minute, cupulate, up to $2 \mathrm{~mm}$ in diam, greyish-orange when dried.

Receptacle two-layered, diameter of hyphae smaller and walls of hyphae thicker in ectal excipulum than in medullary excipulum. Ectal excipulum 50-65 $\mu \mathrm{m}$ thick, consisting of $t$. intricata, hyphae 5-10 $\mu \mathrm{m}$ in diam, wall $1.5-2 \mu \mathrm{m}$ thick. Medullary excipulum 350-390 $\mu$ m thick, t. intricata, hyphae $10-15 \mu \mathrm{m}$ in diam, wall up to $1 \mu \mathrm{m}$ thick. Hyphae are reoriented towards the margin of receptacle, forming $t$. porrecta, their cells becoming longer and more regularly arranged, running parallel with the surface of receptacle, $6-11 \mu \mathrm{m}$ in diam, at obtuse end cells of long hyphae which form the margin. Hypothecium 85-95 $\mu \mathrm{m}$ thick, consisting of $t$. intricata, hyphae 3-5 $\mu \mathrm{m}$ in diam. Hymenium 190-210 $\mu \mathrm{m}$ thick.

Asci with 8 ascospores. Ascospores ellipsoid, hyaline, uniguttulate, (12.6) 13.4-14.4 (15.8) $\times$ (7.2) 7.9-8.5 (9.1) $\mu \mathrm{m}$, excluding ornamentation, $\mathrm{Q}=1.7$. Ornamentation consisting of small warts. Paraphyses straight, up to $3-5 \mu \mathrm{m}$ in diam at the apex.

Grows on calcium-rich soil with mosses.

Specimens examined: Finland.Varsinais-Suomi: Parainen, 6696:234, on Aloina brevirostris, Bryum sp., Ditrichum flexicaule and Encalypta sp., 9.X.1969 Alava \& Alho (TUR); Etelä-Häme: Tammela, on Bryum sp. and Ceratodon purpureus, 27.IX.1866 Karsten (H).

10. Octospora miniata (De Not.) Caillet \& Moyne, Bull. Soc. Mycol. France 96:180. 1980. -Figs. 25B-D, 26A-B, 31C

Lamprospora miniata De Not., Comm. Soc. Critt. Ital. 1:388. 1864.

Apothecium minute, at first cupulate, later flattened, up to $1.5 \mathrm{~mm}$ in diam, reddish-orange when dried. Outside concolorous, glabrous. Margin dentate, fimbriate, at first raised, later backward turned.

Receptacle two-layered, walls of hyphae thicker in ectal excipulum than in medullary excipulum. Ectal excipulum 50-80 $\mu \mathrm{m}$ thick, consisting of $t$. intricata with interwoven epidermoid hyphae, these 8-22 $\mu \mathrm{m}$ in diam, wall 1.5-3 $\mu$ m thick. Medullary excipulum 130-160 $\mu \mathrm{m}$ thick, consisting of $t$. intricata, hyphae 5-8 $\mu \mathrm{m}$ in diam, wall up to $1 \mu \mathrm{m}$ thick. Hyphae are reoriented towards the margin of receptacle, forming $t$. porrecta, their cells becoming longer and more regularly arranged, running parallel with the surface of receptacle, 6-10 $\mu \mathrm{m}$ in diam at obtuse end cells of long hyphae which form the margin. Hypothecium 45-60 $\mu$ m thick, consisting of $t$. intricata, hyphae 3-7 $\mu \mathrm{m}$ in diam. Hymenium 260-270 $\mu$ m thick.

Asci with 8 ascospores. Ascospores globose, hyaline, uniguttulate; reticulate ornamentation may be incomplete on some ascospores, ridges $0.6-0.9 \mu \mathrm{m}$ wide and $0.5-0.9 \mu \mathrm{m}$ high, (13.9) 14.7 (15.8) excluding ornamentation. Paraphyses straight, diam at the apex 3-4 $\mu \mathrm{m}$.

Grows on leaves and stems of the moss Encalypta streptocarpa.

Specimen examined: Finland. Varsinais-Suomi: Särkisalo, 66721:2704, 23.IX.1994 Jakobson (TAA 135663).

11. Octospora rubens (Boud.) M.M. Moser, Kleine Kryptogamenflora IIA, Ascomyceten: 110. 1963. - Figs. 12, 26C-D

Humaria rubens (Boud.) Seaver, The North American Cup-fungi (Operculates): 127. 1928.

Apothecium cupulate, $2-3 \mathrm{~mm}$ in diam, orange when dried.

Receptacle two-layered, ectal excipulum $110-130 \mu \mathrm{m}$ thick, consisting of $t$. intricata, hyphae $10-15 \mu \mathrm{m}$ in diam, wall $2.5-4 \mu \mathrm{m}$ thick. Medullary excipulum 420-960 $\mu \mathrm{m}$ thick, consisting of $t$. intricata, hyphae $20-40 \mu \mathrm{m}$ in diam, wall 1-2 $\mu \mathrm{m}$ thick. In the central part of medullary excipulum vertical orientation of hyphae may occur. Margin consisting of parallel running hyphae which form $t$. porrecta. Hypothecium 50-65 $\mu \mathrm{m}$ thick, consisting of $t$. intricata, hyphae 4-6 $\mu \mathrm{m}$ in diam. Hymenium 180-240 $\mu \mathrm{m}$ thick.

Asci with 8 ascospores. Ascospores ellipsoid, hyaline, with two guttulae, smooth, (15.1) 16.6-17.4 (18.6) × (9.8) 10.4-10.9 (11.6) $\mu \mathrm{m}$, $\mathrm{Q}=1.5-1.6$. Paraphyses slightly clavate, straight or slightly curved, diam at the apex 5-8 $\mu \mathrm{m}$.

Grows on soil with mosses.

Specimens examined: Finland. Kittilän Lappi: Kittilä, with Ditrichum cylindricum, Pogonatum dentatum, Oligotrichum sp, 76748:2530, 16.IX.1991 Väre (OULU); Inarin Lappi: Utsjoki, with Ceratodon purpureus, Ditrichum sp., Polytrichum alpinum, Pohlia sp., 7735:503, 18.IX.1965, Pohjola (TUR). 


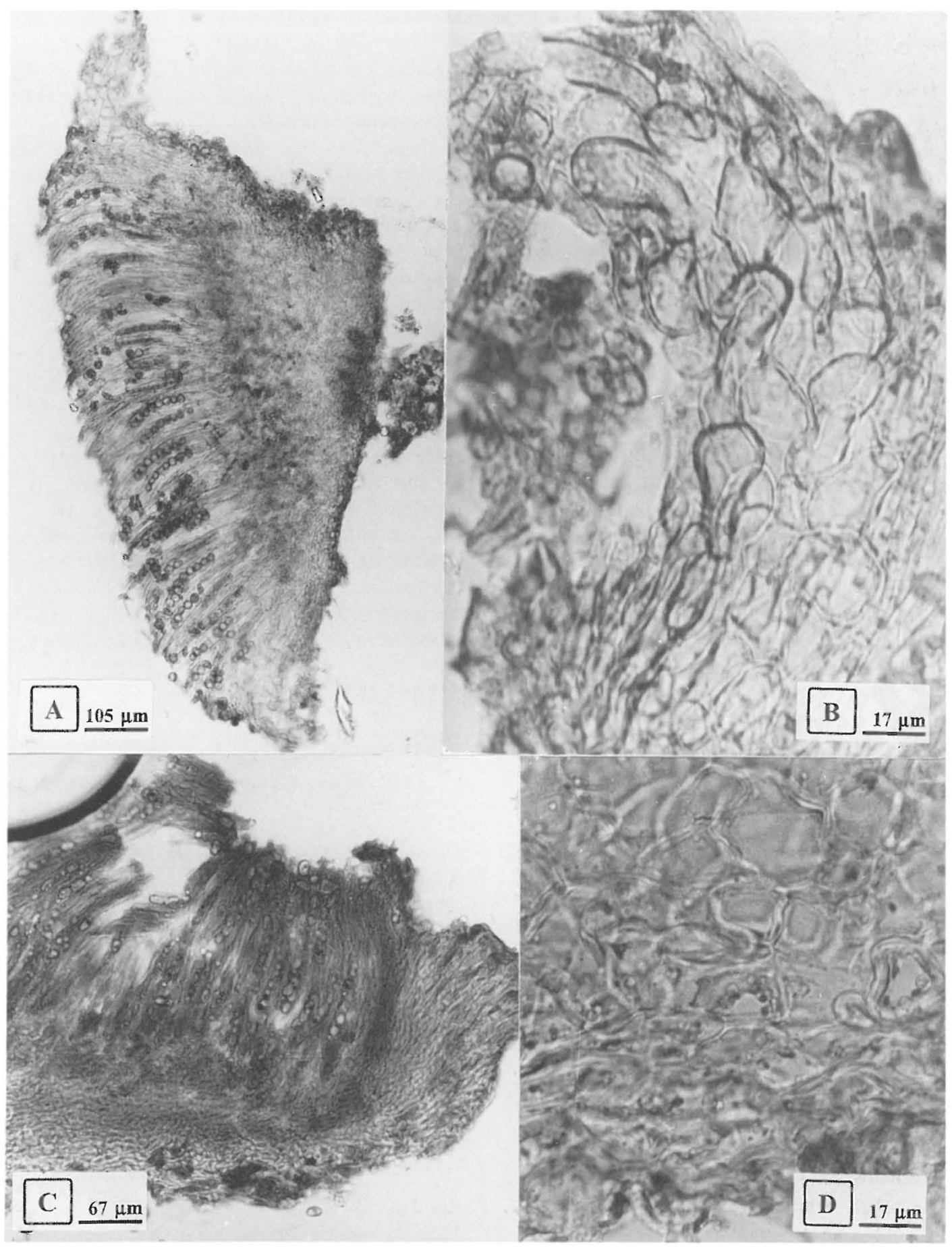

Fig. 26 A-B. Octospora miniata: A) cross-section of fruitbody, B) margin, $t$. porrecta (TAA 135663). - C-D. O. rubens: C) margin, D) ectal excipulum, $t$. porrecta (Pohjola, 18.IX.1965). 
12. Octospora rustica (Velen.) J. Moravec, Česká Mykologie 23:226. 1969. - Figs. 8, 16, 27

Humaria rustica Velen., Monogr. Discom. Bohemiae: 372. 1934.

Octospora libussae Svrček \& Kubička, Česká Mykologie 17:65. 1963.

Apothecium minute, cupulate to discoid, up to 2 $\mathrm{mm}$ in diam, orange when dried. Outside glabrous, concolorous. Margin indistinct.

Receptacle two-layered, walls of hyphae thicker in ectal excipulum than in medullary excipulum. Ectal excipulum 50-55 $\mu \mathrm{m}$ thick, consisting of $t$. intricata, hyphae 6-13 $\mu \mathrm{m}$ in diameter, walls $1.5-2 \mu \mathrm{m}$ thick. Medullary excipulum 160-190 $\mu$ m thick, of $t$. intricata, hyphae $8-15(23) \mu \mathrm{m}$ in diam, wall up to $1 \mu \mathrm{m}$ thick. Hyphae are reoriented towards the margin of receptacle forming $t$. porrecta, their cells becoming longer and more regularly arranged, running parallel with the surface of receptacle, 5$10 \mu \mathrm{m}$ in diam at obtuse end cells which form the margin. Hypothecium 40-55 $\mu \mathrm{m}$ thick, consisting of $t$. intricata, hyphae $4-8 \mu \mathrm{m}$ in diam. Hymenium 150-200 $\mu \mathrm{m}$ thick.

Asci with 8 ascospores. Ascospores asymmetrical, ellipsoid, hyaline, with one or two guttulae, smooth, (13.2) 14.4-15.4 (17.0) $\times$ (7.2) 8.0-9.4 (10.1.) $\mu \mathrm{m}, \mathrm{Q}=1.8$.

Paraphyses straight or slightly curved, in herbarized material slightly clavate consisting of few orange guttulae, apex 4.5-7 $\mu \mathrm{m}$ in diam. Living paraphyses, studied in water, are strongly clavate, diameter at the apex 5.5-14.5 $\mu \mathrm{m}$, filled with orange guttulae.

Grows on fireplaces, on soils rich in calcium or on clay with mosses.

Specimens examined: Estonia. Viljandimaa: Kõpu, on Pohlia sp., 23.IIX.1993 Kullman (TAA 117888). Finland. Varsinais-Suomi: Pöytyä, on Ceratodon purpureus, 6478:269, 21.IX.1994 Jakobson (TAA 135656; TAA 135659); Särkisalo, on Bryum sp. and Dicranella varia, 6672:270, 23.IX.1994 Jakobson (TAA 135664); Pohjois-Häme: Äänekoski, 29.VII.1982, Harmaja (H).

Discussion. O. rustica is similar to $O$. rubens. $O$. rubens has bigger spores and bigger apothecia.

13. Octospora seaveri (Benkert) Yei-Zeng Wang, Special Publ. Natl. Mus. Nat. Sci. Taiwan 4:41. 1992. - Fig. 1
Lamprospora seaveri Benkert, Zeitschr. Mykol. 53:241. 1987.

Apothecium minute, cupulate, up to $1 \mathrm{~mm}$ in diam, hymenium orange when dried. Outside concolorous, glabrous.

Receptacle two-layered, walls of hyphae thicker in ectal excipulum than in medullary excipulum. Ectal excipulum up to $60 \mu \mathrm{m}$ thick, consisting of $t$. intricata with epidermoid hyphae $8-13 \mu \mathrm{m}$ in diam, walls $1.5-2 \mu \mathrm{m}$ thick. Medullary excipulum 260-290 $\mu \mathrm{m}$ thick, of $t$. intricata, hyphae $10-14 \mu \mathrm{m}$ in diam, wall up to $1 \mu \mathrm{m}$ thick. Hyphae are reoriented towards the margin of receptacle forming $t$. porrecta, their cells becoming longer and more regularly arranged, running parallel with the surface of receptacle, $10-22 \mu \mathrm{m}$ in diameter at obtuse end cells which form the margin. Hypothecium 45$65 \mu \mathrm{m}$ thick, consisting of $t$. intricata. Hymenium 210-250 $\mu$ m thick.

Asci with 8 ascospores. Ascospores globose, hyaline, uniguttulate, (13.2) 14.7-14.9 (16.4) $\mu \mathrm{m}$ excluding ornamentation. Reticulate ornamentation, ridges $0.6-1.3 \mu \mathrm{m}$ in diam. Paraphyses straight, slightly clavate, diameter at the apex 4-7 $\mu \mathrm{m}$.

Grows on soil with mosses.

Specimens examined: Finland. Uusimaa: Helsinki, on Bryum sp., Ceratodon purpureus, 05.XI.1860 Nylander (H); Etelä-Häme: Tammela: Mustiala, 26.IX.1866 Karsten $2901(\mathrm{H})$.

Discussion. O. seaveri differs from the other species by globose spores with a more irregular reticulate ornamentation. The specimens described in this paper were identified by Dr. D. Benkert.

14. Octospora tetraspora (Fuckel) Korf, Mycologia 46:838. 1945. - Figs. 9, 28, 29A-B

Ascobolus tetrasporus Fuckel, Hedwigia 5:4. 1866.

Peziza tetraspora (Fuckel) Cooke, Grevillea 3:73. 1874. Humaria tetraspora (Fuckel) Seaver, The North American Cup-Fungi (Operculates): 134. 1928.

Apothecium minute, discoid, up to $2 \mathrm{~mm}$ in diam, hymenium orange when dried, somewhat darker (brownish) than in Octospora leucoloma. Margin not prominent, fimbriate, dentate.

Receptacle two-layered, walls of hyphae thicker in ectal excipulum than in medullary 


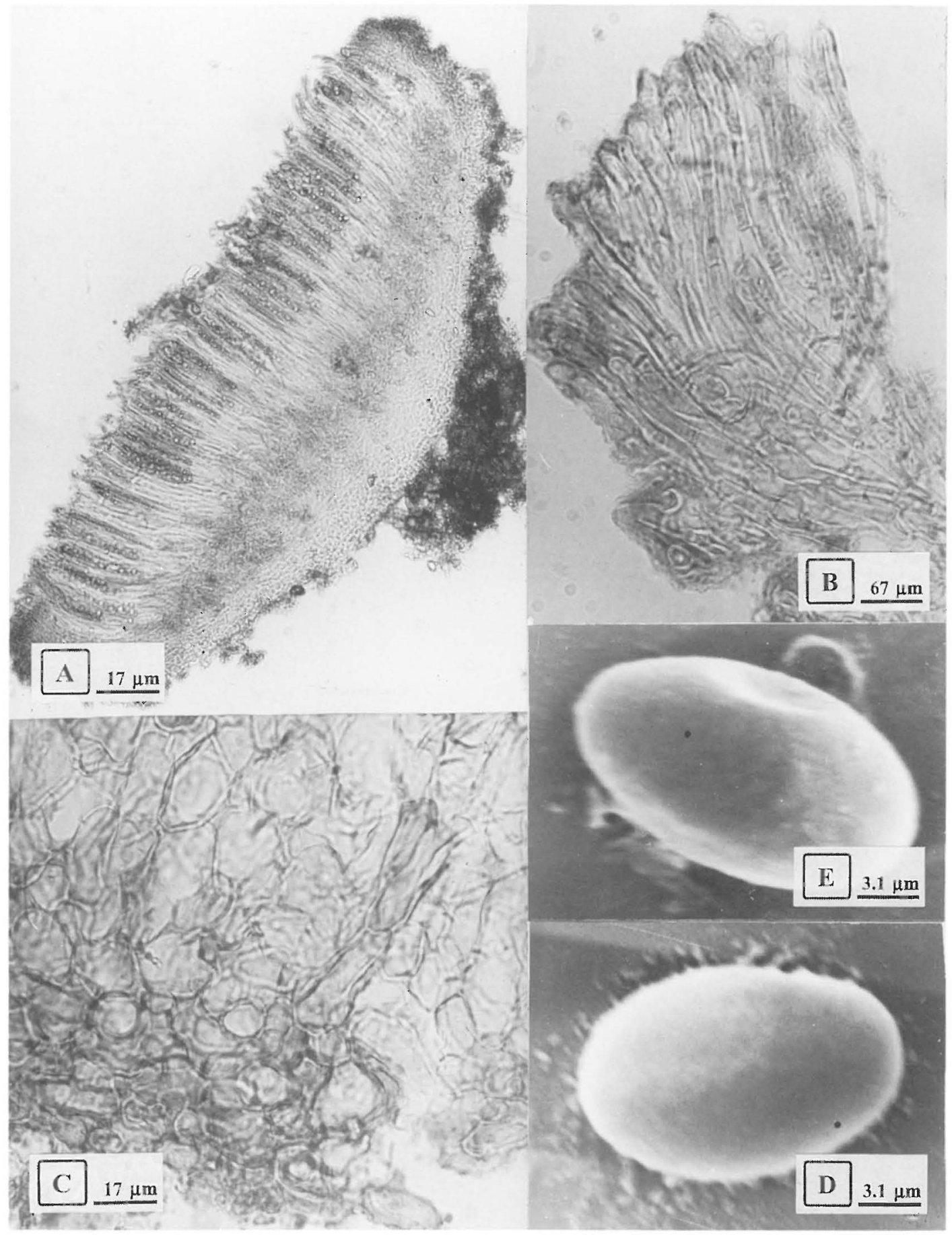

Fig. 27. Octospora rustica: A) cross-section of fruitbody (TAA 135656), B) margin, $t$. porrecta, C) medulla and ectal excipulum, $t$. porrecta (TAA 135664), D-E) spores (TAA 135659). 


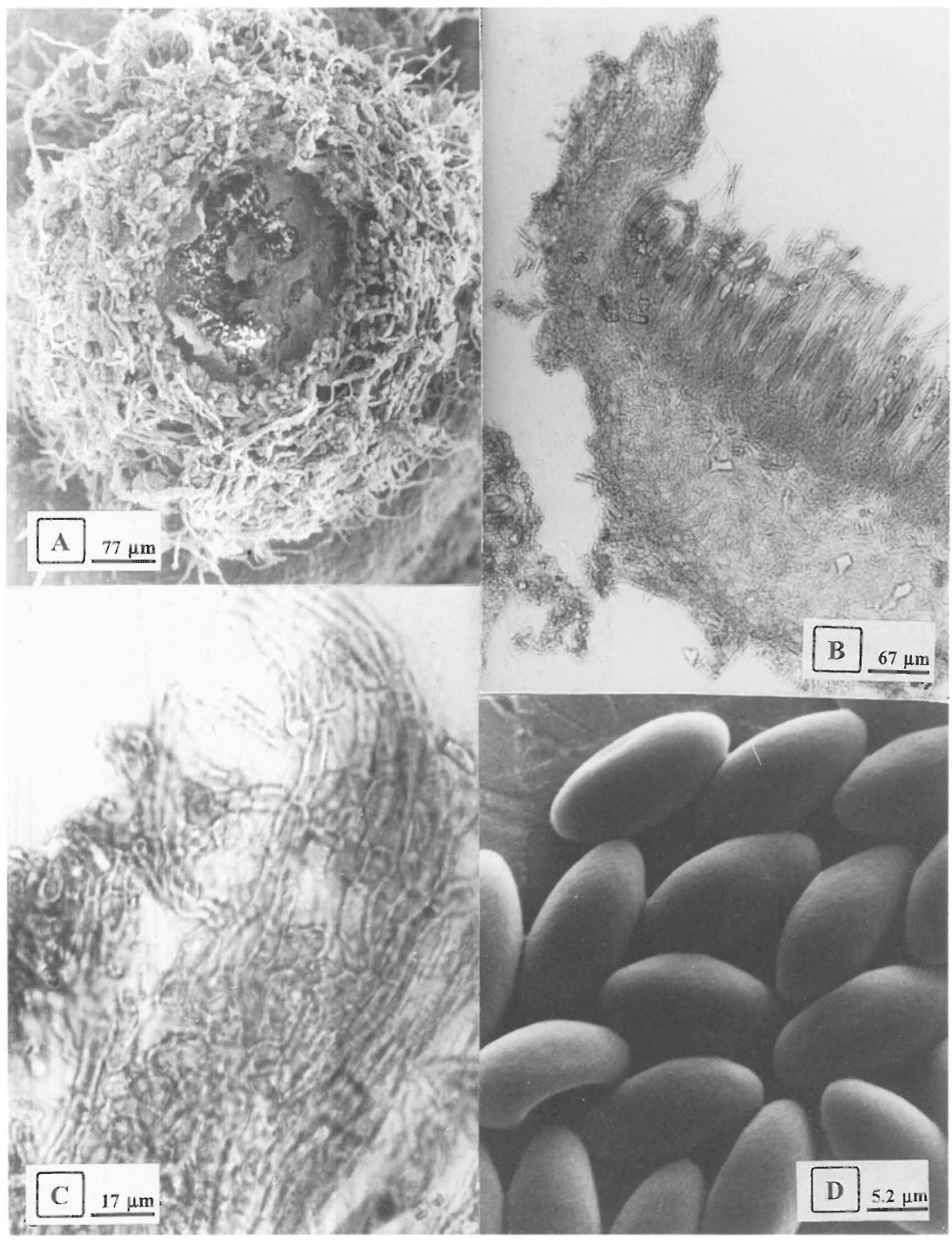

Fig. 28. Octospora tetraspora: A) outer surface of hymenium (TAA 117656), B) cross-section of fruitbody, C) margin, t. porrecta (TAA 117226), D) spores (TAA 117 226). 


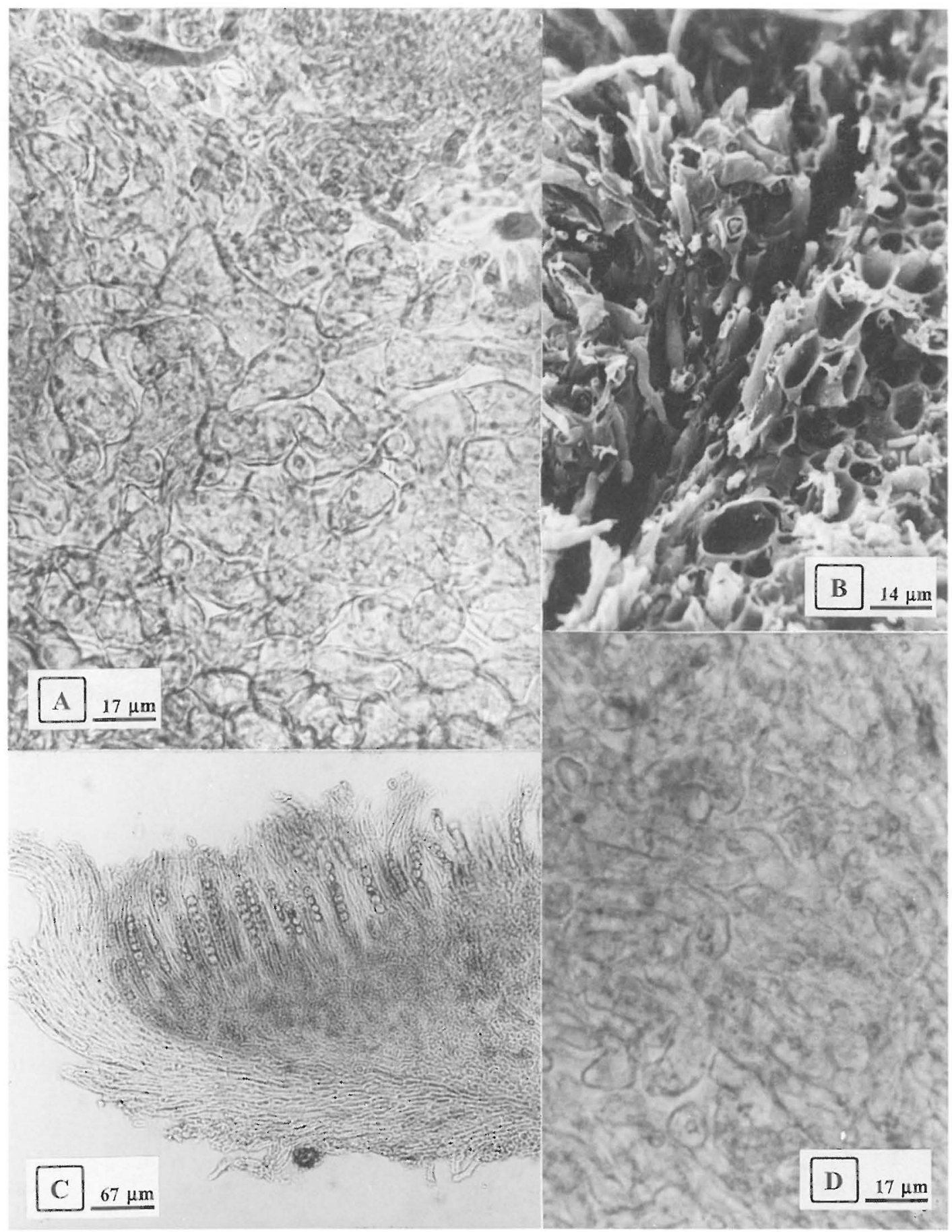

Fig. 29 A-B. Octospora tetraspora: A) ectal excipulum, medulla and hypothecium, $t$. intricata, B) medulla and hypothecium (TAA 117876), - C-D. O. wrightii: C) cross-section of fruitbody, D) medulla, $t$. intricata (TAA 135661). 


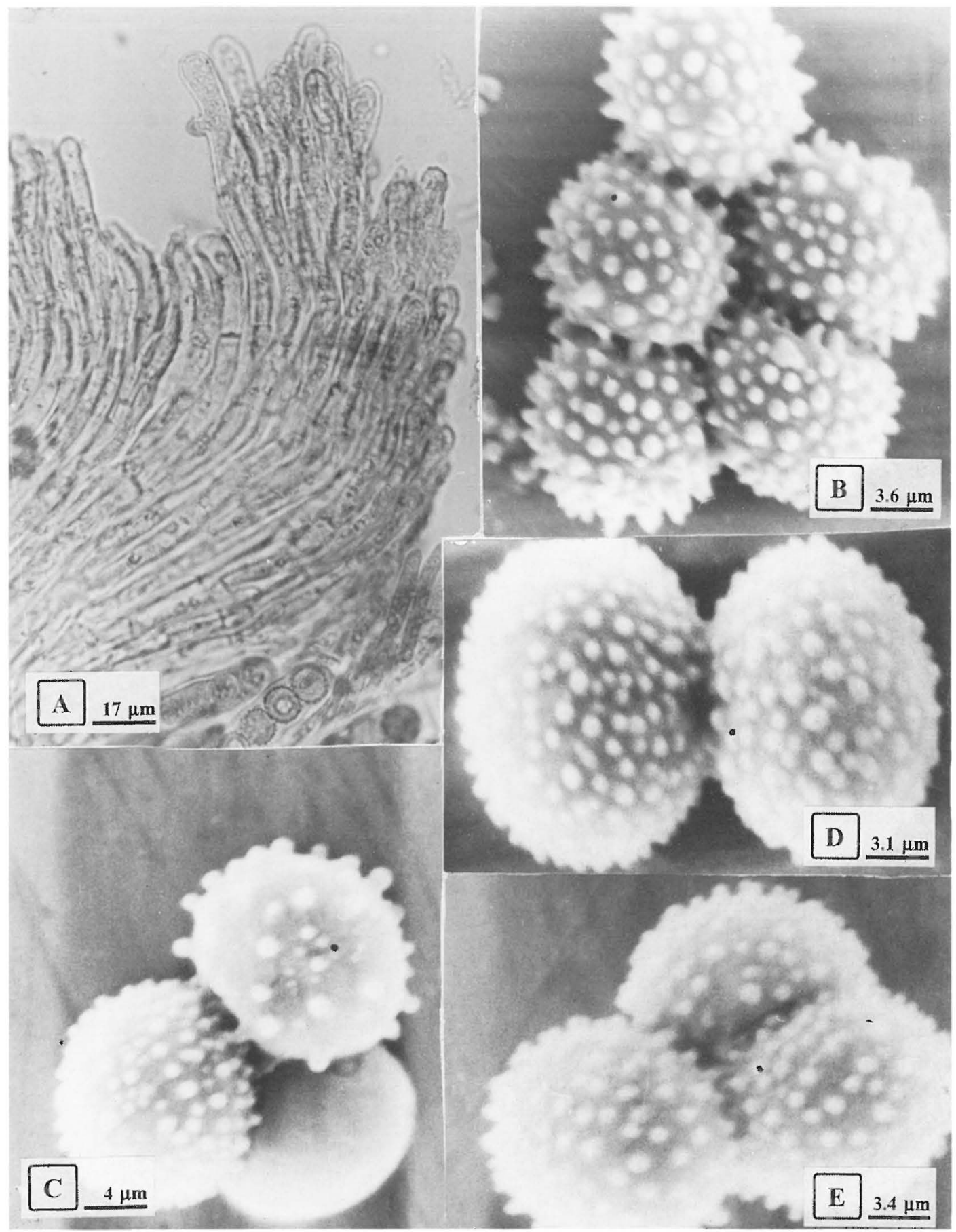

Fig. 30. Octospora wrightii: - A) Margin, t. porrecta. - B-E. Different ornamentation of spores: B) (TAA 135661), C-E) (TAA 135675). 


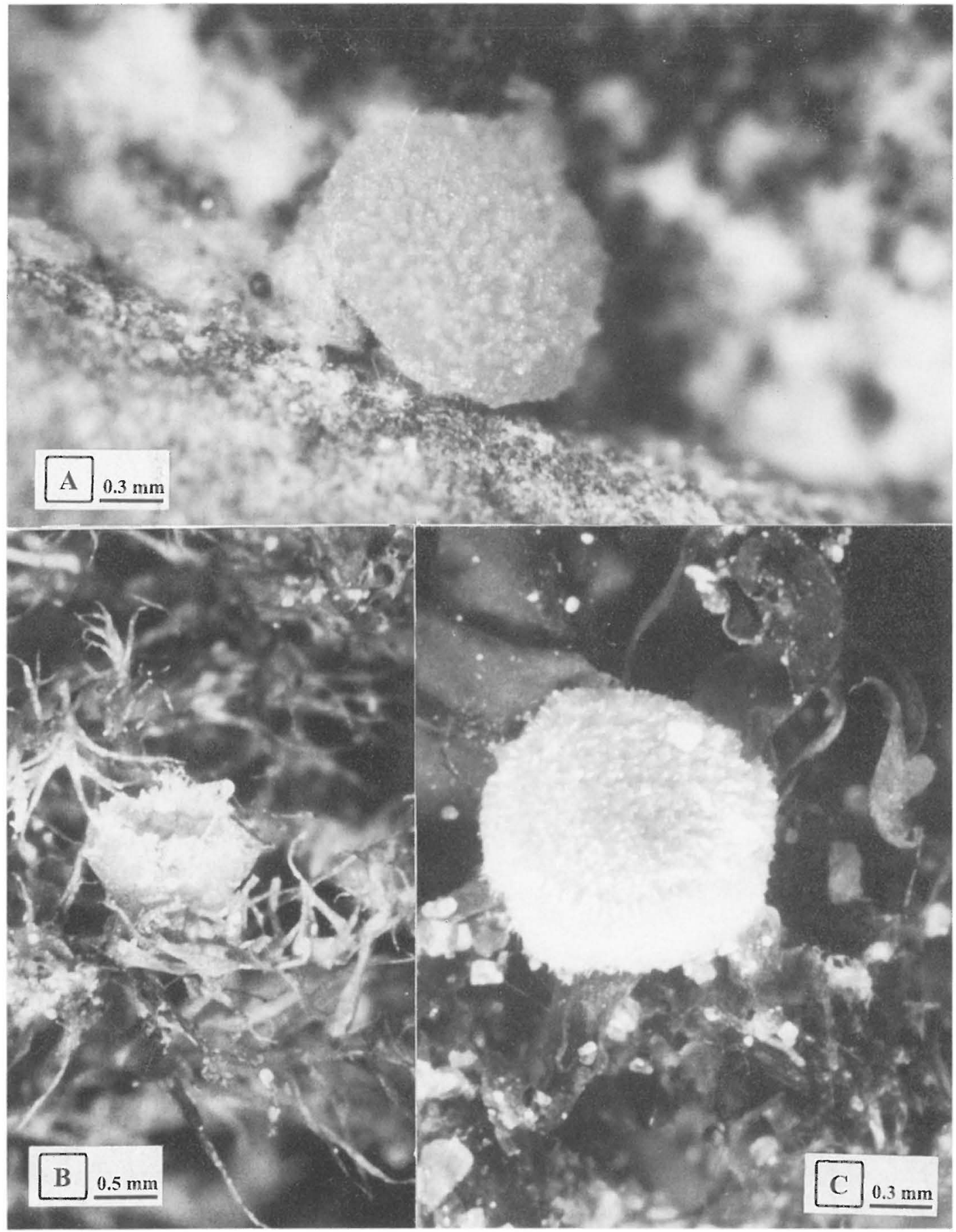

Fig. 31 A. Octospora leucoloma (TAA 135664A). - B. O. wrightii (TAA 135661). - C. O. miniata (TAA 135663). 
excipulum. Ectal excipulum 20-30 $\mu$ m thick, consisting of $t$. intricata, hyphae 5-11 $\mu \mathrm{m}$ in diam, wall up to $1.5 \mu \mathrm{m}$ thick. Medullary excipulum $150-180 \mu \mathrm{m}$ thick, consisting of $t$. intricata, hyphae $7-15 \mu \mathrm{m}$ in diam, wall up to $1 \mu \mathrm{m}$ thick. Hyphae are reoriented towards the margin of receptacle forming $t$. porrecta, their cells becoming longer and more regularly arranged, running parallel with the surface of receptacle, 6-11 $\mu \mathrm{m}$ in diam at obtuse end cells which form the margin. Hypothecium 30-40 $\mu \mathrm{m}$ thick, consisting of $t$. intricata, 3-5 $\mu \mathrm{m}$ in diam.

Asci with 4 ascospores. Ascospores asymmetrical, ellipsoid to subfusoid, hyaline, with one or two big and some small guttulae, smooth, (18.9) 22.0-24.4 (25.2) × (9.5) 10.9$11.3(12.0) \mu \mathrm{m}, \mathrm{Q}=2.1$. Paraphyses clavate, straight or slightly curved, diam at the apex $3.5-4 \mu \mathrm{m}$.

Grows on calcium-rich soil, typically among Bryum argenteum.

Specimens collected between 5 July and 14 November.

Specimens examined: Estonia. Raplamaa: Kohila, 1995 Jakobson (TAA 135682). Viljandimaa: Kõpu, 1993 Kullman (TAA 117876); Loodi, 1989 Kullman (TAA 117226). Tartu: Aardla, 1991 Kullman (TAA 117656); Räni, 1989 Kullman (TAA 117353).

Discussion. O. tetraspora resembles eightspored $O$. leucoloma but differs from it by fourspored asci and bigger ascospores.

15. Octospora wrightii (Berk. \& M.A. Curtis) J. Moravec, Česká Mykologie 23:227. 1969. Figs. 14, 29C-D, 30, 31B

Peziza wrightii Berk. \& M.A. Curtis, Ann. Mag. Nat. Hist. III, 15:444. 1865.

Humaria wrightii Boud., Hist. Class. Discom. Eur.: 68. 1907.

Lamprospora wrightii (Berk. \& M.A. Curtis) Seaver, Mycologia 6:15. 1914.

Apothecium immersed or superficial, minute, at first cupulate, concave, with prominent, thick margin, later flattened, convex, with thin margin, up to $2 \mathrm{~mm}$ in diam, hymenium orange when dried. Outside concolorous, glabrous. Margin fimbriate, dentate.

Receptacle two-layered, walls of hyphae thicker in ectal excipulum than in medullary excipulum. Ectal excipulum 65-100 $\mu$ m thick, consisting of $t$. intricata, hyphae 5-11 $\mu \mathrm{m}$ in diam, wall $1.5-2 \mu \mathrm{m}$ thick. Medullary excipulum 120-190 $\mu \mathrm{m}$ thick, of $t$. intricata, hyphae 8-11 $\mu \mathrm{m}$ in diam, thin-walled, wall up to $1 \mu \mathrm{m}$ thick. Hyphae are reoriented towards the margin of receptacle forming $t$. porrecta, their cells becoming longer and more regularly arranged, running parallel with the surface of receptacle, $8-10 \mu \mathrm{m}$ in diam at obtuse end cells which form the margin. Hypothecium 45-65 $\mu \mathrm{m}$ thick, consisting of $t$. intricata, hyphae $3-6 \mathrm{~mm}$ in diam. Hymenium 160-190 $\mu$ m thick.

Asci with 8 ascospores. Ascospores subglobose to broadly ellipsoid, hyaline, uniguttulate, ornamentation consisting of warts, (12.3) 13.1 (14.5) $\times(10.7) 11.5(12.0) \mu \mathrm{m}$, excluding ornamentation, $\mathrm{Q}=1.2$. Paraphyses straight, slightly clavate, diam at the apex 4.5-9.5 $\mu \mathrm{m}$.

Grows on sandy soil on stems and leaves or among the moss Amblystegium serpens.

Specimens examined: Estonia. Tartumaa: Tartu, UTM 3316, 27.V.-10.X.1995 Jakobson (TAA 135675). Finland. Varsinais-Suomi: Särkisalo, 6672:270, 23.IX.1994 Jakobson (TAA 135661).

Discussion. When measured in water from a living apothecium immediately after collecting, the diameter of the apex of paraphyses was 4.5$5.5 \mu \mathrm{m}$, after being exposed for 2 hours to high humidity in a box, the diameter was 7.5-9.5 $\mu \mathrm{m}$ (Fig. 14.).

The length of asci from the same apothecium was found to be very variable. Differences in the length on matured living asci were almost twofold, from 110 to $200 \mu \mathrm{m}$ (Fig. 14). Such a difference may be caused by the fact that the tips of matured asci arise clearly above the level of the hymenium. This effect can be seen only on a living apothecium.

$O$. wrightii is characterized by the subglobose spores and by their tuberculate ornamentation. O. wrightii is always found with the moss Amblystegium serpens. It is phenologically interesting that the Estonian specimen was collected from the same place during a very long period (27.05.-10.10.).

16. Octospora sp., TAA 118091. - Fig. 7

Apothecium semi-immersed, minute, discoid, concave, up to $1.5 \mathrm{~mm}$ in diam, hymenium reddish-orange when dried. Outside concolorous, 
covered with hyphae which anchor apothecium to the substrate. Margin not prominent, thin, fimbriate.

Receptacle two-layered, walls of hyphae thicker in ectal excipulum than in medullary excipulum. Ectal excipulum 50-55 $\mu \mathrm{m}$ thick, consisting of $t$. intricata, hyphae $8-14 \mu \mathrm{m}$ in diam, wall $2-3 \mu \mathrm{m}$ thick. Medullary excipulum 65-80 $\mu \mathrm{m}$ thick, of $t$. intricata, hyphae 8-13 $\mu \mathrm{m}$ in diam, thin-walled, wall up to $1 \mu \mathrm{m}$ thick. Hyphae are reoriented towards the margin of receptacle forming $t$. porrecta, their cells becoming longer and more regularly arranged, running parallel with the surface of receptacle, 8$13 \mu \mathrm{m}$ in diam at obtuse end cells which form the margin. Hypothecium 30-55 $\mu \mathrm{m}$ thick, consisting of $t$. intricata, hyphae 5-7 $\mu \mathrm{m}$ in diam. Hymenium 275-300 $\mu$ m thick.

Asci with 8 ascospores. Ascospores ellipsoid to subfusoid, hyaline, with one or occasionally two guttulae, smooth, (22.7) 24.1 (26.5) $\times$ (11.7) 12.4 (13.9) $\mu \mathrm{m}, \mathrm{Q}=1.9$. Paraphyses clavate, straight, diam at the apex 3.5-4 $\mu \mathrm{m}$.

Grows on soil with Ceratodon purpureus.

Specimen examined: Estonia. Läänemaa: Palivere, 24.IX.1994 Kullman (TAA 118091).

Discussion. This specimen is similar to $O$. axillaris but differs from it by broader spores. The value of $\mathrm{Q}$ for spores of $O$. axillaris is commonly higher than 2 (2.2 in this work); however, the value of $\mathrm{Q}$ for spores of this specimen is 1.9.

Acknowledgements. This research was supported by the Estonian Science Foundation grant No. 131 and Center for International Mobility (CIMO) as well as by the University of Turku. We thank Dr. Mart Rahi (Institute of Zoology and Botany) for assistance in work with SEM, as well as Kimmo Syrjänen (University of Turku), Nele Ingerpuu (Institute of Zoology and Botany) for identifying the mosses and Ms. Ester Jaigma for revising the English text of the manuscript.

\section{References}

Benkert, D. 1987: Beiträge zur Taxonomie der Gattung Lamprospora (Pezizales). - Zeitschr. Mykol. 53:195271.

Benkert, D. 1990: Zwei neue Arten der Gattung Lamprospora (Pezizales, Ascomycetes). - Feddes Repert. 101:631-637.

Caillet, M. \& Moyne, G. 1980: Contribution du genre à l'étude Octospora Hedw. ex S.F. Gray emend Le Gal. Espèces a spores ornementées, globuleuses ou subglobuleuses. - Bull. Soc. Mycol. France 96:175-211.
Caillet, M. \& Moyne, G. 1987: Contribution à l'étude du genre Octospora Hedw. ex S.F. Gray (Pezizales). Espèces a spores elliptiques ou fusiformes. - Bull. Soc. Mycol. France 103:179-226.

Dietrich, H.A. 1856: Blicke in die Cryptogamenwelt der Ostseeprovinzen. - Arch. Naturk. Liv-, Esth-, Kurlnds, II ser., 1:261-416.

Dietrich, H.A. 1859: Blicke in die Cryptogamenwelt der Ostseeprovinzen. Zweite Abteilung. - Arch. Naturk. Liv-, Esth-, Kurlands, II ser., 1:487-538.

Dissing, H. 1981: Four new species of Discomycetes (Pezizales) [Fungi] from West Greenland. - Mycologia. 73:263-273.

Dissing, H. \& Sivertsen, S. 1983: Operculate Discomycetes from Rana (Norway) 4. Octospora hygrohypnophila, Peziza prosthetica and Scutellinia mirabilis spp. nov. - Nordic J. Bot. 3:415-421.

Engel, H. \& Hanff, B. 1985: In Nordwestoberfranken gefundene Arten der Gattung Octospora Hedwig ex S.F.Gray. - Die Pilzflora Nordwestoberfrankens 9:3-20.

Engel, H. \& Hanff, B. 1987: In Nordwestoberfranken und seinen angrenzenden Gebieten (Unterfranken) gefundene Arten der Gattungen Lamprospora De Notaris und Ramsbottomia W.D.Buckley emend. D.Benkert u. T.Schumacher. - Die Pilzflora Nordwestoberfrankens 11/A:3-31.

Huhtinen, S. 1987: New Svalbard fungi. - In: Laursen, G.A. \& Ammirati, J.F. (eds.). - Arctic and alpine mycology 2:123-151.

Itzerott, H. 1981: Die Gattung Octospora mit besonderer Berücksichtigung der Pfälzer Arten. - Nova Hedwigia 34:265-283.

Kullman, B. 1991: Octospora tetraspora as four-spored O. leucoloma? - Cryptog. Bot. 2:115-117.

Kullman, B. 1997: A very rare discomycete, Octospora maireana, found in Finland. - Karstenia 37:27-33.

Raitviir, A. 1963: Notes on the taxonomy of Pezizales. Proc. Acad. Sci. Estonian SSR, Biol. 12:325-333. (in Russian).

Schumacher, T. 1979: Operculate discomycete (Pezizales) on river banks in Norway. - Norweg. J. Bot. 26:53-83.

Schumacher, T. 1993: Studies in arctic and alpine Lamprospora species. - Sydowia 45:307-337.

Wang, Y.Z. \& Kimbrough, J.W. 1992: Monographic studies of American species of Octospora previously ascribed to Lamprospora (Pezizales, Ascomycetes). Special Publ. Natl. Mus. Nat. Sci. Taiwan 4:1-68.

Received on 10 January 1997 